\title{
The Politics of International Redistribution: Explaining Public Support for Fiscal Transfers in the EU
}

\author{
Hanna Kleider \\ University of Georgia, USA \\ hkleider@uga.edu \\ Florian Stoeckel \\ University of Exeter \\ florian.stoeckel@gmail.com
}

\begin{abstract}
:
As a consequence of the Eurozone crisis and the creation of the European Stability Mechanism (ESM), the prospect of a transfer union has become a particularly contested aspect of European integration. How should we understand the public backlash against fiscal transfers? And, what explains voter preferences for international transfers more generally? Using data from the from the 2014 European Elections Study, we conduct the first crossnational analysis of voters' preferences on international transfers. Our analysis reveals a strong association between voters' non-economic cultural orientations, i.e. their cosmopolitanism, and their position on transfers. At the same time, we find that voters' economic left-right orientations are crucial for a fuller understanding of the public conflict over transfers. This counters previous research that finds economic left-right orientations to be of little explanatory value. We demonstrate that the association between economic leftright orientations and preferences for international transfers is conditional on a person's social class. Among citizens in a high income class an economically left-leaning position is associated with support for transfers, whereas it is associated with opposition to transfers among citizens in a low income class.
\end{abstract}

\section{Keywords}

Eurozone crisis, international redistribution, cosmopolitanism, political ideology, material self-interest

\section{Acknowledgements}

We would like to thank Liesbet Hooghe, Evelyne Huber, Swen Hutter, Hanspeter Kriesi, Theresa Kuhn, Michael Lewis-Beck, John Stephens, and Konstantin Vössing as well as the anonymous reviewers for their helpful comments and thoughtful suggestions. Earlier versions of the paper were presented at the Council for European Studies Meeting in 2016, at the APSA Meeting in 2016, and at the Workshop "Rejected Europe. Beloved Europe. Cleavage Europe?" at the European University Institute in 2017. This paper was previously circulated under the title "Left-wing but unwilling to support international redistribution? Explaining public support for fiscal transfers in the EU." All remaining errors are our own. 


\section{INTRODUCTION}

In the wake of the international financial crisis, European elites devised the European Stability Mechanism (ESM), a financial assistance program designed to avert economic and financial meltdown in a number of European countries. The ESM, which is funded by contributions from its member states, has been considered the largest international transfer scheme in history since World War II (Bechtel et al. 2014). Its creation has made the costs of European integration more visible to voters and has resulted in a fierce public backlash. In most member states of the European Union (EU), a majority of voters oppose the idea of financially assisting other member states (Schmitt et al. 2015).

In this article, we seek to understand the determinants of voters' preferences on financial assistance in the context of the recent crisis, and on EU fiscal transfers more generally. Because financial assistance measures were an economic response to events that revealed the vulnerability of modern capitalism, one would have expected them to reinforce economic left-right divisions among voters and political parties. Nevertheless, recent studies suggest that the creation of these measures created a cultural conflict instead, one that cuts across the established economic left-right divide and pitches centrist pro-European parties and their voters against anti-integration extremists on both sides of the left-right spectrum (Hooghe and Marks 2017; Kriesi et al. 2012; Bechtel et al. 2014). Aside from examining purely individual-level differences in preferences on EU transfers, this article also looks at the macroeconomic context in which they are embedded.

We draw on diverse strands of literature to develop a set of theoretical explanations for voters' preferences on EU transfers. The first strand focuses on individual differences in cultural openness and cosmopolitanism (Bechtel et al. 2014; Kuhn and Stoeckel 2014), the second account emphasizes the importance of ideological left-right dispositions, and the third approach centers on material self-interest (Hainmueller and Hiscox 2010; Burgoon 2014). 
Lastly, we incorporate macroeconomic context factors and examine how they shape individuals' preferences on EU transfers.

We examine our hypotheses using data from the European Election Study (EES) 2014, which surveyed roughly 1,000 individuals in each of the 28 EU member states (Schmitt et al. 2015). The EES 2014 includes a unique question about the extent to which respondents find it desirable to financially assist other EU member states. It also contains a broad range of survey items on respondents' political ideology and their material circumstances.

Our analysis shows that cultural orientations are associated with preferences on EU transfers across all 28 countries in our sample. Culturally open voters support EU transfers, whereas culturally closed voters oppose them. This finding extends previous studies that have examined the association between cultural openness and support for EU transfers among German voters (Bechtel et al. 2014; Bechtel et al. 2017; Stoeckel and Kuhn 2017). A core finding in our study is that in addition to noneconomic cultural orientations, economic leftright positions are also important predictors of voters' preferences on transfers. This counters previous research, which found economic left-right positions to be of little explanatory value. ${ }^{1}$ We show that the way in which economic left-right positions are associated with preferences for EU transfers depends on a person's material circumstances. Among voters in a high income class, an economically left-leaning position is associated with support for EU transfers. Among voters in a low income class, by contrast, an economically left-leaning position is associated with strong opposition to EU transfers.

We argue that this is because high-income left-leaning voters - those whose basic safety and sustenance needs have been fulfilled - can afford to extend their values about a

\footnotetext{
${ }^{1}$ For recent arguments in favor of considering economic alongside noneconomic considerations see Häusermann and Kriesi 2015; Hooghe and Marks 2016.
} 
fair and more equal society at home toward the international level. ${ }^{2}$ But low-income leftleaning voters, who could be hurt by the transfer program's potential downward pressure on domestic welfare spending, might fear that their material well-being is at risk. To be clear, we do not suggest that low-income left-leaning voters do not share the same values about fairness and equality as high-income left-leaning voters. Rather, we argue that their material self-interest considerations may trump these values when it comes to EU transfers. ${ }^{3}$

The 28 European countries in our sample are not identical in terms of key economic characteristics, particularly in the extent to which they have struggled with current account deficits. We therefore account for economic performance data as well as for net contributions to the EU budget, Eurozone membership, and the receipt of bailout funds through the European Stability Mechanism (ESM). We find that citizens' willingness to contribute to EU fiscal transfers is lower in countries with a smaller GNI per capita. Citizens in these countries seem to perceive their government's ability to contribute to a fiscal transfer program as highly constrained and are likely to believe that the responsibility for stabilizing the region lies with the EU's high-income countries. Interacting macroeconomic context variables with individual-level predictors, we find that support for EU transfers is lowest among left-leaning low-income individuals in poorer EU countries and strongest among left-leaning high-income individuals in richer EU countries.

We conclude by discussing the implications of our findings for the prospects of mainstream political parties. In the light of continuing international economic integration, we expect increasing tensions within mainstream parties, particularly on the left. Leftist parties will find it very difficult to bridge the tension between their high-income and internationally

\footnotetext{
${ }^{2}$ One could of course contend that high-income voters fear higher taxation as a result of EU transfers. However, previous research on international fiscal rescues and on immigration has found little evidence that concerns about rising taxes drive high-income voters' preferences. See Broz 2005; Bechtel et al. 2014.

${ }^{3}$ For a related argument, see Rueda and Stegmueller 2016.
} 
oriented supporters and their traditional worker clientele, the latter of whom might feel betrayed by their party's support for economic integration.

\section{EU FISCAL TRANSFERS}

Fiscal transfers have long been a key element of the EU's economic governance. Traditional transfer programs, like the European Structural and Investment Funds, did however not face the same public backlash as the ESM and the prospect of a comprehensive transfer union. ${ }^{4}$ A fiscal transfer union, viewed by numerous observers as a necessary response to the recent Eurozone crisis (Krugman 2011), is strongly opposed by others, many of whom have already viewed the ESM with great skepticism. ${ }^{5}$ Understanding voters' preferences on financial assistance in the context of the economic crisis, and on fiscal transfers more generally, will be essential to devising durable and accepted policy solutions (Habermas 2017).

\section{The case for the cultural left-right}

Existing efforts to understand the public divide over EU transfers in the context of the economic crisis have largely been informed by research in international political economy, since voters' preferences on issues like trade, immigration, and foreign aid seem to exhibit a similar structure (Bechtel et al. 2014; Daniele and Geys 2015; Scheve and Slaughter 2001a, 2001b; Broz 2005; Mayda 2006). Contrary to earlier work in international political economy, which centered on economic self-interest explanations, more recent studies have argued that

\footnotetext{
${ }^{4}$ The ESM falls short of a transfer union, although it is sometimes presented as such in public discourse. It grants loans to governments who can no longer access capital on private markets due to the prohibitive interest rates they would have to pay. Governments receive loans in exchange for reforms and repay loans on the agreed maturity date.

${ }^{5}$ Alternative proposals envision a version of fiscal federalism, see Enderlein (2015).
} 
individuals' preferences on international economic issues are best predicted by differences in cultural openness. These more recent studies find that voters who are culturally open and cosmopolitan tend to show more support for international trade, immigration, and European economic integration. Culturally closed voters, by contrast, tend to oppose international economic integration (Hainmueller and Hiscox 2006, 2007, 2010; Hooghe and Marks 2005, 2009; McLaren 2004; Kuhn and Stoeckel 2014). Research suggests that culturally open and cosmopolitan voters are more supportive of issues like international trade and immigration because they have a more encompassing definition of political community, which allows them to perceive of international economic integration as less of a threat to their national identity (Sniderman et al. 2004). Drawing on these insights to examine the divide over EU transfers, Bechtel et al. (2014) find that cosmopolitanism is the most important factor in explaining support for transfers among German voters. Their analysis shows that German voters who are more cosmopolitan tend to view bailouts of Eurozone countries more favorably than culturally closed voters do (Bechtel et al. 2014). In a similar vein, Kuhn et al. (2017) as well as Verhaegen (2017) find that voters with a stronger European identity - as opposed to an exclusive national identity - are more supportive of EU solidarity.

The finding that cultural openness, rather than economic self-interest, explains support for EU transfers has implications for domestic political contestation. If voters' preferences over EU transfers are best explained by cultural orientations, then the emerging divide over transfers is likely to reinforce a new noneconomic cultural dimension of domestic political contestation that cross-cuts the established economic left-right dimension (Hooghe et al. 2002; Kriesi et al. 2012; Bechtel et al. 2014). The cultural dimension pitches green, alternative, and libertarian parties and voters against more traditional authoritarian and 
nationalist ones (Hooghe et al. 2002). ${ }^{6}$ Bechtel et al. find that where "support for these financial transfers exhibits a cross-cutting ideological pattern rather than a left-right divide, attitudes differ most significantly between supporters of centrist parties and extremist parties, whereby the latter are significantly less supportive of bailouts" (2014: 836). In line with this strand of literature, we therefore expect that voters' preferences on EU transfers will be best predicted by individual differences in cultural openness and will map onto a noneconomic cultural dimension of political contestation.

\section{The case for the economic left-right}

\section{Ideological dispositions}

It is also plausible that aspects of the current conflict over EU fiscal transfers are being absorbed into the traditional economic left-right dimension of political contestation. After all, the issue of EU fiscal transfers touches upon fundamental economic questions regarding the appropriate role of government, the redistribution of income and wealth, and the regulation of markets. There are several possibilities in relating the debate about EU fiscal transfers to the traditional economic left-right dimension.

One possibility would be to examine whether domestic left-right ideology extends to the international level; i.e. voters might carry coherent policy preferences across various domestic and international redistribution issues because these issues are rooted in similar values and beliefs. ${ }^{7}$ For instance, research suggests that preferences for domestic redistribution and preferences for international development assistance form a coherent pattern that reflects similar underlying goals, with citizens who support domestic redistribution also favoring development assistance (Lumsdaine 1993). We would therefore

\footnotetext{
${ }^{6}$ Kitschelt (1994) calls it the authoritarian-libertarian dimension, while Kriesi et al. (2012) use the term globalization cleavage.

${ }^{7}$ We thank one of our anonymous reviewers for this idea.
} 
expect a left-leaning belief in a fair and more equal society to be associated with both more support for domestic redistribution and a more favorable position toward EU fiscal transfers, although the former involves redistributing between individuals and the latter involves redistributing between territories (Marks and Steenbergen 2002).

A coherent preference pattern founded on similar values and beliefs presumes that values and beliefs exert an important effect on policy preferences that is largely independent of economic self-interest. Although much research has shown that economic self-interest is a key predictor of preferences on left-right policies (Cusack et al. 2006; Iversen and Soskice 2001; Rehm 2009), there is growing evidence to suggest that values and beliefs about equality, fairness and distributive justice are equally important in predicting economic leftright positions. Such values appear to have a strong effect on economic left-right policy preferences, even when accounting for economic self-interest variables such as people's position in the labor market, their exposure to the risk of layoffs, and their financial standing (Picketty 1995, Fong 2001, Corneo and Grüner 2002, Alesina and Ferrara 2004). Indeed, economic left-right policy preferences seem to be best explained by a mixture of economic self-interest and values about fairness and equality, where values are understood as abstract beliefs about desirable end states (Margalit 2013; Alesina and La Ferrera 2005; Corneo and Grüner 2002; Fong 2001). ${ }^{8}$ Corneo and Grüner even suggest that individuals tend to support the redistributive program "which conforms with their vision of what constitutes a good policy for society as a whole", rather than the one that maximizes their economic benefit (Corneo and Grüner 2002: 84). Values and beliefs about equality and fairness also seem to be very persistent over time and are only temporarily set off by changing material circumstances (Margalit 2013).

\footnotetext{
${ }^{8}$ A stronger belief that economic hardships are due to external rather than individual factors also increases support for redistributive policies (Picketty 1995; Alesina and La Ferrera 2005; Petersen et al. 2011; Margalit 2013).
} 
Assuming that similar values and beliefs generate a coherent preference pattern across domestic and international issues, we would therefore expect that economically left-leaning voters who support domestic redistribution would be more favorable to EU transfers than voters with an economically right-leaning disposition.

\section{Economic self-interest}

A second possibility would be to treat preferences on EU transfers and the economic left-right dimension as being linked through economic self-interest considerations. For instance, the international political economy literature suggests that the traditional support base of left-leaning parties - low-income and low-skilled workers ${ }^{9}$ - incurs the biggest economic losses from international economic integration. Low-income and low-skilled workers are likely to suffer not only from intensified labor-market competition, but also from the downward pressure economic integration can exert on domestic redistributive programs (Scheve and Slaughter 2001a, 2001b; Broz 2005; Hainmueller and Hiscox 2010; Burgoon 2014; Bechtel et al. 2014). On the other hand, the likely supporters of right-leaning parties highly skilled and highly mobile voters - tend to benefit from international economic integration. Several scholars have therefore hypothesized that economically left-leaning voters will become defensive and hostile toward international economic integration while right-leaning, pro-market voters will support it (Marks and Wilson 2000; Kriesi et al. 2006). ${ }^{10}$

These two possibilities for relating preferences on EU transfers to the traditional economic left-right dimension - one focused on values and beliefs about equality and fairness and the other centering on economic self-interest - may not be mutually exclusive. A third possibility would be to examine potentially interactive mechanisms. For example, we expect

\footnotetext{
${ }^{9}$ Meltzer and Richard 1981; Svallfors 2004

${ }^{10}$ Kriesi et al. 2006 formulate this expectation with respect to the classical left and not the "Third Way" leftist parties. See for example Marks and Wilson 2000. Marks and Wilson also show that by the 1990s most leftist parties had taken on a more pro-European integration position and had come to view the EU is the only way of regaining power over business actors in a globalized world.
} 
that the way in which values and beliefs about equality and fairness shape voters' preferences on EU transfers is systematically moderated by economic self-interest considerations: the only economically left-leaning voters likely to extend their values and beliefs about a fair and equal society to the international level are those whose material well-being is unlikely to be undermined. We would therefore predict that economically left-leaning voters in a high income class whose basic sustenance needs have been fulfilled are particularly likely to support EU transfers. ${ }^{11}$ By contrast, economically left-leaning voters whose economic wellbeing could be adversely affected because of the transfer scheme's potential downward pressure on domestic resources for redistribution might not be able to translate their leftist values to the international level (Noël and Thérien 2002). ${ }^{12}$ Economically left-leaning voters in a low income class might be more likely to be opposed to EU transfers. In sum, we would expect that moving up in terms of social class can increase left-leaning voters' ability to afford generosity. It is less clear how an improvement in material circumstances would affect preferences on EU transfers among voters with an economically right-leaning disposition, given the potential increase in the tax burden and the fact that such voters are less predisposed to support EU transfers to begin with. ${ }^{13}$

$<$ Figure 1: Theory on preferences regarding EU transfers $>$

\section{Macroeconomic context}

Voters' preferences on EU transfers are also likely to be shaped by the broader macroeconomic context. Traditionally the literature on European integration has argued that citizens living in poorer EU member states that are net receivers of EU funds tend to be more

\footnotetext{
${ }^{11}$ For a related argument see Rueda and Stegmueller 2016.

${ }^{12}$ Noël and Thérien's Study looks at associations between country-level aggregates in public opinion rather than examining associations between preferences at the individual level.

${ }^{13}$ For empirical evidence on this argument see Broz 2005 and Bechtel et al. 2014.
} 
supportive of European integration than citizens in net contributor countries (Anderson and Reichert 1995; Hooghe and Marks 2005). In the context of the euro crisis, however, a somewhat different picture emerged. Countries that struggled with severe current account deficits, such as Greece, Spain, and Portugal, required bailouts from surplus countries and had no choice but to accept the burden of adjustment in the form of harsh austerity measures. Citizens in deficit countries were therefore understandably not unambiguously positive toward the European Union despite their countries being the likely recipients of ESM funds (Laffan 2016).

It is also plausible that individuals in poorer EU member states viewed their countries' ability to contribute to EU transfer mechanisms as highly constrained. They were likely to believe that the richer member states are the ones to be on the hook with respect to funding a transfer mechanism that mitigates structural differences in the European Union. Indeed, recent research suggests that support for contributing to EU-wide solidarity programs is lower in poorer countries (Lengfeld et al. 2015; Kuhn et al. 2017).

A country's macroeconomic context is also likely to interact in interesting ways with individual-level characteristics. For instance, preferences on EU transfers are likely to differ depending on whether high-income individuals live in a rich EU member state or a poor EU member state. The same may apply to low-income individuals who might have different preferences depending on whether they live in a rich or poor member state (Beramendi and Stegmueller 2016; Beramendi 2012). We hypothesize that the perceived resource conflict between domestic redistribution and EU transfers intensifies as a country's macroeconomic situation worsens. When economic performance is poor, low-income voters might be even more inclined to perceive a trade-off between domestic redistribution on the one hand and EU transfers on the other. We would therefore expect support for EU transfers to be lowest 
among economically left-leaning low-income voters in poorer countries, whereas support should be highest among economically left-leaning, high-income voters in richer countries.

\section{DATA AND MEASUREMENT}

Our empirical analysis draws upon the European Election Study (EES) 2014. This survey offers data for all $28 \mathrm{EU}$ member states and includes roughly 1,000 respondents per country. To operationalize our dependent variable, we rely on a survey item that asks respondents about the extent to which they support the transfer of fiscal resources from their own country to another EU member state.

"To what extent do you agree or disagree with the following statement: In times of crisis, it is desirable for [respondents' country] to give financial help to another EU Member State facing severe economic and financial difficulties?" [Response categories: 1 "totally disagree," 2 "tend to disagree," 3 "tend to agree," 4 "totally agree"]

This question does not ask whether respondents generally find a transfer of resources between member states desirable or whether they expect their country to benefit from it. It captures the extent to which the respondent's country of residence should contribute to such a mechanism, thereby making the costliness of transfers salient. ${ }^{14}$ While we think that the EES question is a useful measure, it might tap something in addition to support for EU transfers. On the one hand our dependent variables asks about citizens' willingness to help fellow EU member states that are experiencing an acute crisis, rather than about their willingness to support a more institutionalized transfer system. Research on support for humanitarian aid suggests that there is an immediacy bias in judgments and decisions about helping others;

\footnotetext{
${ }^{14}$ The results are similar when excluding countries that received financial assistance from EU institutions such as the ESM and its predecessors (Tables A7 and A10).
} 
that is, individuals are more likely to donate to acute crises that arouse immediate emotion (Huber et al. 2011). We would therefore assume that there is more support for helping EU member states facing acute economic and financial difficulties, than for a more institutionalized EU transfer mechanism. On the other hand, our dependent variable asks about preferences for redistributing between countries rather than between social classes within the same country. Support for any type of redistributive system is, however, often believed to be contingent on a preexisting national community with its dense networks, interactions, and generalized trust, which would imply that there is only a weak public mandate for redistribution beyond national borders. Furthermore, the recipients of transnational redistribution are first and foremost other governments and only at a later point individuals. This might decrease support among respondents who would like to see their government help citizens of another EU member state, but not its government or banking sector. We believe that this survey item, although it might tap additional considerations, captures citizens' preferences for EU fiscal transfers relatively well. It also has the advantage of being comparable to items used in recent research on EU transfers and EU solidarity (Bechtel et al. 2014, Kuhn et al. 2017).

Based on Hooghe and Marks (2005: 431) we capture citizens' location on the cultural dimension of political conflict with a continuous measure for sociocultural openness and a dummy variable for exclusive national identity. First, we construct a continuous cultural openness scale that includes attitudes toward a) immigration, b) same-sex marriage, and c) constraints on privacy rights. We then combine these three items using a principal component analysis. Low values represent a culturally open position and high values a culturally closed position. ${ }^{15}$ Second, we include a dummy variable that takes on a value of zero if respondents

\footnotetext{
${ }^{15}$ There is a vast empirical literature showing that economic left-right and cultural GAL-TAN orientations constitute two distinct dimensions (see for instance Hooghe and Marks 2009, Kriesi et al. 2012). Unsurprisingly, the correlation between our measures for the economic left-right and the cultural GAL-TAN dimension is low (see online Appendix Table A11).
} 
simultaneously identify with their own nation and with Europe and a value of one if respondents hold an exclusive national identity (Hooghe and Marks 2005; Risse 2010).

We measure economic left-right positions with a standard question on support for domestic redistribution. This question asks whether respondents are fully opposed to "the redistribution of wealth from the rich to the poor" in their country $(0)$, fully in favor of the redistribution of wealth (10), or somewhere in between. Low values on this measure represent opposition to domestic redistribution and imply an economically right-leaning position, whereas high values are associated with support for domestic redistribution and a left-leaning position. This question captures respondents' economic left-right positions more accurately than a left-right self-placement question, which is likely to evoke both economic and cultural considerations. To check the robustness of our findings, we also include an alternative measure of economic left-right positions that asks about respondents' willingness to support state intervention. ${ }^{16}$

In line with previous research (Svallfors 2004; Iversen and Soskice 2006) we use selfreported social class membership as a proxy for a person's material circumstances. The EES social class measure identifies three social classes: low income, middle income, and high income. Since social class combines a range of disparate economic conditions like education, income, and occupation, we examine the robustness of our findings by including a series of more fine-grained measures that capture different facets of social class. First, we include measure of educational attainment as a substitute for social class. We expect the effect of educational attainment to point in the same direction as the effect of social class, with leftleaning voters in the lowest educational category being more strongly opposed to EU transfers and voters in the highest educational category being more supportive. Next, we account for respondents' financial standing. Unfortunately the EES does not include a

\footnotetext{
${ }^{16}$ The effects of this measure are statistically significant, but slightly less strong. Please see Appendix (A8).
} 
measure of household income, so we proxy financial standing with a survey question that asks if respondents have had trouble paying their bills in the last twelve months "most of the time," "from time to time," or "almost never/never." We expect that left-leaning respondents who have experienced substantial financial troubles will be strongly opposed to EU transfers. By contrast, we expect left-leaning respondents without such troubles to be supportive of EU transfers. Third, we use occupational categories in the EES following a scheme developed by Oesch (2006). ${ }^{17}$ We analyze these occupational categories with dummy variables. We expect low-skilled left-leaning respondents to be strongly opposed to EU transfers, while we suspect that left-leaning professionals and managers will be supportive of EU transfers.

Following convention, we further control for citizens' level of support for European integration (see Appendix B for the question wording). Citizens have been shown to differentiate between the political and economic integration of EU member states (Kuhn and Stoeckel 2014). Individuals might support European integration, but oppose transfers between richer and poorer member states, or they might oppose transfers between EU member states because they are Euroskeptics to begin with. This is a confounding factor we want to account for. Further control variables include age and gender.

Our theoretical model also predicts that a country's economic performance shapes citizens' views on EU transfers, so we account for a series of economic performance indicators that include a member state's GNI per capita (logged), its budget deficit and its debt, as well as its net contributions to the EU budget as a percent of GNI using data from the 2013 EU budget.

Furthermore, we include a dummy variable for countries that are Eurozone members. Although the transfer of EU funds concerns all EU member states, the recent and salient steps toward a transfer union - like the ESM - concern only Eurozone member states. This makes

\footnotetext{
${ }^{17}$ Oesch does not provide a class scheme for the European Election Study (EES), so we have adapted his schemes for the European Social Study (ESS) and the International Social Survey Programme (ISSP) to fit the survey items available to us on the EES (see Table A4, appendix).
} 
fiscal transfers more salient and costly for citizens of Eurozone member states. We also test whether our models are robust to the exclusion of non-Eurozone members. To get a more accurate picture of how the Eurocrisis affects individual preferences for EU transfers, we also account for those countries that have received bailout funds through the ESM, namely Portugal, Ireland, Cyprus, Greece, and Spain. Additionally, we exclude these ESM recipient countries in another robustness test to check whether our results hold. ${ }^{18}$

In line with previous research, we also control for welfare-state generosity using the share of social expenditure as a percentage of GDP (Noël and Thérien 2002). On the one hand, citizens in countries with a larger welfare state might be more opposed to EU transfers since they have more resources to lose. On the other hand, a larger welfare state that provides a significant safety net could alleviate the conflict between resources used for domestic purposes and resources dedicated to international purposes. Low-income citizens in countries with a larger welfare state might therefore be less concerned about a negative effect of EU transfers on their material well-being (Noël and Thérien 2002).

We begin by examining descriptive statistics. The EES 2014 data reveal substantial variation in support across the EU-28. ${ }^{19}$ Support for EU member fiscal transfers ranges from 1 (totally disagree) to 4 (totally agree). It is highest in Sweden (3.05) and lowest in Cyprus (1.99), with a mean of 2.45. Overall, we find that citizens' willingness to contribute to transfers is much lower in countries with a lower GNI per capita than in countries with higher GNI per capita. We suspect that citizens in low GNI per capita countries do not see their governments as being in a position to contribute to EU transfer schemes given their countries' difficult economic situation. The descriptive pattern also suggests that support for EU transfers is lowest in countries that receive funds from the EU or the ESM, with the partial exception of Ireland.

\footnotetext{
${ }^{18}$ Please see Table A7.

${ }^{19}$ All analyses are conducted based on the EU-28. The results are similar in all substantive respects when we restrict the sample to Eurozone member states (Table A6).
} 
$<$ Figure 2: Mean support for EU transfers and GNI per capita by country >

However, about 91 percent of the variation in support for EU transfers is at the individual level. ${ }^{20}$ Figure 3 reflects mean levels of support for EU transfers for three different groups: economically right-leaning voters (those who oppose domestic redistribution), centrist voters, and economically left-leaning voters who prefer a higher level of domestic redistribution. The figure shows that economically left-leaning respondents exhibit slightly lower levels of support for EU transfers than right-leaning respondents.

If our theoretical expectations are accurate, an economically left-leaning position should only be associated with opposition to EU transfers among those individuals who face a perceived or real material "resource conflict." Figure 4 therefore presents economically leftleaning voters by different social classes. As theorized, economically left-leaning individuals in the low income class are the ones most strongly opposed to EU transfers, while economically left-leaning individuals in a high income class have a much more favorable view of EU transfers. The expected pattern is also confirmed when looking at different occupational groups (Figure 4, bottom). Economically left-leaning voters who are either unskilled or unemployed express the lowest level of support for EU transfers. Economically left-leaning self-employed professionals and managers, by contrast, express higher levels of support for EU transfers.

$<$ Figure 3: Support for EU transfers by levels of support for domestic redistribution > $<$ Figure 4: Support for EU transfers by class and occupation $>$

\footnotetext{
${ }^{20}$ The intra-class correlation coefficient is .087 .
} 


\section{RESULTS}

The descriptive statistics presented in the previous section suggest that our expectations about individuals' preferences on EU transfers might be supported by the data. We now analyze the same data using a multilevel regression model, which allows us to include both individual-level and country-level predictors while also accounting for the clustered structure of the data (Steenbergen and Jones 2002). We are primarily interested in interaction effects, which can be understood more intuitively in the framework of a linear model. The results of an ordered logit multilevel model and a hierarchical model with a linear link function are very similar and are shown in the Appendix (Table A3).

$<$ Table 1. Multilevel model, determinants of support for EU transfers $>$

The results of our multilevel regression analysis support our expectations regarding the association between cultural orientations and preferences on EU transfers. The two variables that capture citizens' orientations on the cultural dimension of political conflict the cultural ideology scale and the national identity measure - are important predictors of support for EU transfers (Table 1, Models 1-3). Voters who are culturally closed are more likely to oppose fiscal transfers in Europe, whereas culturally open voters tend to support them. Similarly, individuals who hold an exclusively national identity are less supportive of EU transfers than individuals who hold a national and European identity simultaneously.

Do our results also suggest that economic left-right positions are relevant to explaining the divide over EU transfers? Model 1 shows that an economically left-leaning position alone, measured as support for domestic redistribution, does not have a statistically significant effect on support for EU transfers. This finding is in line with our expectations and with previous research (Bansak et al. 2016: 25). 
Yet, as we predicted, the way in which economic left-right positions are related to support for EU transfers depends on material circumstances. Model 2 includes an interaction between economic left-right positions and social class. The marginal effects plot (Figure 5) shows that an increase in support for domestic redistribution - our measure for economic leftright positions - is negatively related to support for EU transfers among individuals in a low income class, whose material well-being might be adversely affected by EU transfers. In contrast, an increase in support for domestic redistribution is positively associated with support for EU transfers among individuals in a high income class. Among high-income voters, an economically left-leaning position leads to a more favorable view of EU transfers. We believe that these high-income voters are economically secure and therefore able to transfer their left-leaning beliefs and values about fairness and equality to the European level.

To help us interpret these findings, Figure 6 shows predicted values of support for EU transfers among individuals in a low income class (straight line) and individuals in a high income class (dashed line). Among individuals in a low income class, support for domestic redistribution is associated with decreasing support for EU transfers. This means that lowincome, economically left-leaning individuals are less supportive of EU transfers than lowincome, economically right-leaning individuals. Among individuals in a high income class, by contrast, an economically left-leaning position is associated with increasing support for EU transfers. High-income, economically left-leaning voters are more supportive of EU transfers than high-income right-leaning voters. The fact that none of the previous studies have accounted for a moderating effect of material circumstances might explain their null finding for the effect of economic left-right ideology.

$<$ Figure 5: Marginal effect of support for domestic redistribution on EU transfers by social class >

$<$ Figure 6: Support for EU transfers by social class $>$ 
Given that self-reported social class may be an inexact proxy of a respondent's economic circumstances, we now examine whether our results are robust to alternative measures. Our alternative measures are typically considered subdimensions of social class and include an indicator of a respondent's educational attainment, a measure of a respondent's financial troubles and a measure of occupational status, which we code following Oesch (2006).

Our findings using a measure of educational attainment point in a similar direction to our analysis based on social-class (Table 2, Figure 7). Among respondents in the lowest educational category, that is, those with no formal education and those who left school at the age of fifteen, an economically left-leaning orientation is associated with opposition to EU transfers. In contrast, among respondents in the highest educational category who received education after the age of twenty, an economically left-leaning position is associated with support for EU transfers. Likewise, among respondents who experienced financial trouble within the last twelve months, an economically left-leaning orientation - measured as support for domestic redistribution - is associated with lower support for EU transfers, whereas this is not the case among respondents who have not faced such financial trouble. We obtain similar findings when using occupational categories. Among unemployed and unskilled workers, an economically left-leaning orientation produces lower support for EU transfers, whereas it is associated with higher support for EU transfers among self-employed professionals and among managers. To illustrate the interactions graphically and to provide a sense of their substantive meaning, Figure 7 shows the marginal effects of economic left-right orientations by class, education, financial standing, and occupation.

$<$ Table 2. Multilevel model, determinants of support for EU transfers (alternative measures for social class) > 
$<$ Figure 7: Marginal effects of a two standard deviation change in support for domestic redistribution by social class, education, financial standing, and occupation. >

These results lend additional support to our theory: economically left-leaning, high income citizens are the group most supportive of EU transfers. They are significantly more supportive of EU transfers than economically right-leaning high-income citizens, regardless of their cultural values. Economically left-leaning low-income individuals, by contrast, are the ones most strongly opposed to EU transfers, more strongly even than low-income rightleaning voters. They might perceive their material well-being to be at risk from an EU transfer scheme that could take resources away from domestic programs and are therefore not likely to translate their values about equality and fairness to the international level.

Examining the effect of our control variables, we also find that older individuals and those respondents who support European integration are more likely to support EU transfers, while women are less likely to support EU transfers.

How does a country's macroeconomic situation influence the extent to which its citizens support EU transfers? First, we examine the effect of logged GNI per capita, ${ }^{21}$ deficit, debt, and social spending as a percentage of GDP (Table 1). Only GNI per capita has statistically significant effect. Individuals in countries with a higher GNI per capita exhibit more support for EU transfers than individuals in countries with a lower GNI per capita. ${ }^{22}$

Second, we examine the influence of a country's net contributions to the EU budget, its Eurozone membership, and its ESM recipient status. We do not find any added effect for a country's net contributions to the EU budget once a country's GNI per capita is controlled for

\footnotetext{
${ }^{21}$ Alternatively, we can use a country's GDP per capita (logged) as a measure of economic performance. The results are very similar.

${ }^{22}$ Figure 8, which shows predicted levels of support for EU transfers, further illustrates this point. Support for EU transfers in poorer countries (Figure 7a: line 1, Figure 7b: line 3) is lower than in richer countries (Figure 7a: line 2, Figure 7b: line 4).
} 
(Table A5). ${ }^{23}$ We also test whether our results hold once we restrict our sample to only those countries that are net contributors to the EU budget, and we find that our results remain unchanged (Table A10). In a next step, we examine the influence of Eurozone membership. We find that support for EU transfers is lower in countries that are members of the Eurozone (Table 1), which is likely because of the increased salience of transfer schemes in Eurozone member states. If we restrict our sample to just Eurozone member states, our results still hold (Table A6). Lastly, we test whether our results hold if we exclude ESM recipient countries from the sample (Table A7), given that preference-formation processes in these countries might be different because of the acute balance of payments problems they have experienced. Our main substantive results are confirmed even when we exclude ESM recipients.

$<$ Figure 8: Support for EU transfers by social class and GNI per capita >

Third, we analyze whether a country's macroeconomic situation conditions the way in which economic left-right positions and social class relate to support for EU transfers. We therefore include a three-way interaction in Model 3 between economic left-right positions, social class, and a country's GNI per capita. Following Dawson and Richter (2006), we evaluate the average marginal effect of economic left-right positions for four distinct groups (see Figure 8): citizens in a high income class in poor countries (1), citizens in a high income class in rich countries (2), citizens in a low income class in poor countries (3), and citizens in a low income class in rich countries (4). We define a country as poor if its GNI per capita is

\footnotetext{
${ }^{23}$ The results also hold when controlling for net contributions to the EU budget as a percentage of a country's GNI (see Table A5). Inserting net contributions to the EU budget into our models, we find that: (1) all other results still hold, and (2) individuals in net-recipient countries do not exhibit consistently and significantly different views of EU transfers than do individuals in net-contributor countries after controlling for GNI per capita. However, whether an EU member state is a net contributor or net receiver is closely related to its GNI per capita. Hence net contributions correlate highly with our GNI per capita variable. In order to prevent multicollinearity from affecting the results, we have excluded net contributions in the main models we display. Moreover, we believe that the mechanism relating net contributions and views of EU-level redistributions is essentially the same as that which relates GNI and EU-level redistributions: it is the fact that scarce resources (at the macro level) decrease citizens' willingness to help other EU member states.
} 
one standard deviation below the EU-28 mean (e.g., Romania, Bulgaria, and Latvia) and we define a country as rich if its GNI per capita is one standard deviation above the EU-28 mean (e.g., Luxembourg and Sweden).

We find that economically left-leaning voters in a low income class in poor EU member states exhibit the lowest level of support for EU transfers, lower even than lowincome left-leaning voters in richer EU member states. In other words, for low-income voters, residence in a poor country amplifies the negative association between a left-leaning position and support for EU transfers. By contrast, economically left-leaning voters in a high income class in richer countries express the highest level of support for EU transfers, higher than left-leaning high-income citizens in poorer countries. This means that among highincome citizens, living in a rich country amplifies the positive association between a leftleaning position and support for EU transfers. Of the six possible comparisons between these four groups, five are statistically different from one another ( $p<.05$ or less), which lends additional credibility to our findings. ${ }^{24}$

Furthermore, we seek to shed light on the causal mechanism that links a country's economic performance to its citizens' support for EU transfers. We suspect that the effect of a country's GNI per capita is mediated by citizens' views on whether their government can afford to financially assist other EU countries. In other words, citizens in countries with a higher GNI per capita should be more likely to support EU transfers because they believe that their country can afford contributions to EU transfer mechanisms. Unfortunately the EES does not include a survey item that directly asks respondents about their views on what their country can afford. To test our argument, therefore, we revert to a measure of retrospective sociotropic economic evaluations, commonly used in research on voting behavior, which asks

\footnotetext{
24 The comparisons between the four different groups are shown in the Appendix (Table A2). Out of the six possible comparisons, only the difference between high-income individuals in poorer countries and low-income individuals in richer countries is not statistically significant.
} 
whether respondents believe that their country's economic situation has been deteriorating during the preceding twelve months (Lewis-Beck and Stegmaier 2000). A deteriorating economy implies that fewer public resources are available. If our argument is correct, citizens who believe that their country's economy has been deteriorating should be less likely to support EU transfers. First we calculate an aggregate measure of retrospective sociotropic evaluations for each country and include it as a substitute for GNI per capita in our main model (Table A14, appendix). The result shows that support for EU transfers is higher in countries where fewer citizens believe that the economic situation has been deteriorating. In a second step, we conduct a causal mediation analysis with individual-level data on retrospective sociotropic evaluations (Baron and Kenney 1986). We find that GNI per capita predicts voters' subjective evaluations of the state of the economy, which themselves predict support for EU transfers (Table A16 and A17, appendix). Including subjective evaluations of the economy alongside GNI per capita in the same model decreases the effect of GNI per capita on support for EU transfers compared to a model in which only GNI per capita predicts support for EU transfers. These results are consistent with partial mediation (Baron and Kenney 1986: 1176): the effect of GNI per capita on support for EU transfers is partially mediated by perceptions of the well-being of the economy. ${ }^{25}$

\section{CONCLUSION}

Most experts agree that a transfer program offering financial assistance to Eurozone countries facing adverse economic shocks is necessary to restore the stability of the region (Krugman 2011). Even so, instruments like the European Stability Mechanism have provoked a fierce public debate. Many voters strongly oppose a transfer of resources to assist other

\footnotetext{
${ }^{25}$ We checked the robustness of this pattern with a measure for prospective economic evaluations, which is a measure for expectations regarding the economy during the upcoming year, and we can confirm these findings (Table A16, appendix).
} 
countries. In a number of European countries, this public dissatisfaction has given rise to new challenger parties, such as the radical right "Alternative for Germany." A long-term policy solution must therefore be based on a better understanding of voters' preferences on redistributive transfers in Europe.

Our analysis extends current research, which understands the divide over EU transfers primarily as a cultural conflict that pitches culturally closed political parties and their voters against culturally open parties and voters (Bechtel et al. 2014). We find that across all 28 EU member states, cultural orientations are strongly associated with preferences on EU transfers. We also find, however, that economic left-right positions are relevant for a more comprehensive understanding of voters' preferences on international redistribution.

Our analysis shows that among voters in a high income class, an economically leftleaning position is associated with significantly higher levels of support for EU transfers than a right-leaning orientation, even when controlling for cultural openness. Among voters in a low income class, by contrast, a left-leaning position is associated with a strong opposition to EU transfers.

What could explain these diverging responses? We believe that left-leaning individuals in a high income class can afford to translate their leftist values and belief system about a fair and equal society to the international level, whereas this might not be the case among leftleaning voters in a low income class. Seeing that they might be among the losers of a transfer mechanism that redistributes a country's fiscal resources to other EU member states and exerts a downward pressure on domestic resources, economically left-leaning voters with lower incomes may allow their material self-interest to trump their otherwise leftist values about equality and fairness. Ultimately, economic left-right orientations are double-edged: they express a set of universal values about equality and fairness, and they express material 
self-interest. Where these two elements are in conflict, perceived material self-interest prevails. Where they are not in conflict, values prevail. ${ }^{26}$

Our analysis further shows that citizens in poorer EU member states are less willing to contribute to a European transfer mechanism than citizens in richer member states. In fact, economically left-leaning low-income citizens in poor EU member states exhibit the strongest opposition to EU transfers. This leads us to believe that poor macroeconomic conditions can aggravate a perceived "resource conflict" between domestic redistribution and international redistribution.

Our findings are consistent with a growing number of studies that find noneconomic cultural considerations to be important factors in explaining voters' preferences on international economic issues like immigration, trade, financial rescues, and European economic integration (Hainmueller and Hiscox 2006, 2007, 2010; Hooghe and Marks 2005; Risse 2010; Kuhn and Stoeckel 2014; Bechtel et al. 2014). These studies suggest that the complexity of international economic policies makes cultural frames more appealing, while the distributional consequences are less easily evaluated. Our findings, however, also show that cultural accounts are incomplete and that individuals' economic left-right positions are necessary for a more comprehensive understanding of mass attitudes on international economic issues. Economically left-leaning individuals in a high income class are consistently more supportive of international fiscal transfers than right-leaning individuals, irrespective of their cultural orientation. Economically left-leaning citizens in a low income class, by contrast, are extremely opposed to EU transfers. The same preference pattern is likely to appear when examining other economic issues, for instance the extension of welfare benefits to immigrants or the level of support for foreign aid.

\footnotetext{
${ }^{26}$ We thank one of our anonymous reviewers for this formulation.
} 
It is clear that the multidimensionality of economic left-right positions makes it problematic for leftist political parties to position themselves on the issue of international redistribution. Arguing in favor of assisting economically struggling EU members may earn leftist parties the endorsement of economically left-leaning high-income voters, but it could cost them their traditional working-class clientele. Our analysis provides a useful framework for understanding the electoral struggles of leftist parties in an era of economic integration, as well as their failure to delay the shrinking of their traditional socioeconomic base. With working-class voters among the real or perceived losers in a globalized society, leftist parties' positive stance on economic integration is increasingly likely to be viewed as a betrayal. 


\section{Bibliography}

Alesina, Alberto, and Eliana La Ferrara. 2005. Preferences for redistribution in the land of opportunities. Journal of Public Economics 89 (5): 897-931.

Anderson, Christopher J. and M. Shawn Reichert. 1995. Economic Benefits and Support for Membership in the E.U.: A Cross-National Analysis. Journal of Public Policy 15: 23149.

Bansak, Kirk, Michael Bechtel, Jens Hainmueller, and Yotam Margalit. 2016. The Ideological Basis of the Grexit Debate. Stanford University Graduate School of Business Research Paper No. 16-9.

Baron, Reuben M., and David A. Kenny. 1986. The Moderator-Mediator Variable Distinction in Social Psychological Research: Conceptual, Strategic, and Statistical Considerations. Journal of Personality and Social Psychology 51 (6): 1173-1182.

Bechtel, Michael, Jens Hainmueller, and Yotam Margalit. 2014. Preferences for International Redistribution. The Divide over the Eurozone Bailouts. American Journal of Political Science, 58 (4): 835-856.

Bechtel, Michael, Hainmueller, Jens, and Yotam Margalit. 2017. Policy design and domestic support for international bailouts. European Journal of Political Research. online first

Beramendi, Pablo. 2012. The Political Geography of Inequality: Regions and Redistribution. Camebridge: Cambridge University Press.

Beramendi, Pablo, and Stegmueller, Daniel. 2016. The Political Geography of the Eurocrisis. CAGE Online Working Paper Series 278, Competitive Advantage in the Global Economy (CAGE).

Broz, J. Lawrence. 2005. Congressional politics of international financial rescues. American Journal of Political Science 49 (3): 479-496.

Burgoon, Brian. 2014. Immigration, Integration, and Support for Redistribution in Europe. World Politics 66 (03): 365-405.

Corneo, Giacomo, and Hans Peter Grüner. 2002. Individual Preferences for Political Redistribution. Journal of Public Economics 83 (1): 83-107.

Cusack, Thomas, Torben Iversen, and Philipp Rehm. 2006. Risks at Work: The Demand and Supply Sides of Government Redistribution. Oxford Review of Economic Policy 22 (3): 365-389. 
Daniele, Gianmarco, and Benny Geys. 2015. Public Support for European Fiscal Integration in Times of Crisis. Journal of European Public Policy 22 (5): 650-670.

Dawson, Jeremy F., and Andreas W. Richter. 2006. Probing Three-Way Interactions in Moderated Multiple Regression: Development and Application of a Slope Difference Test. Journal of Applied Psychology 91 (4): 917-926.

Enderlein, Henrik. 2015. Towards an Ever Closer Economic and Monetary Union? The Politics and Economics of Exploratory Governance. In Beyond the Crisis: The Governance of Europe's Economic, Political and Legal Transformation, edited by Mark Dawson, Henrik Enderlein, and Christian Joerges,13-23. Oxford: Oxford University Press.

Fong, Christina. 2001. Social Preferences, Self-interest, and the Demand for Redistribution. Journal of Public Economics 82 (2): 225-246.

Habermas, Juergen. 2017. Why The Necessary Cooperation Does Not Happen: Introduction To A Conversation Between Emmanuel Macron And Sigmar Gabriel On Europe's Future. Social Europe, March 20, 2017. https://www.socialeurope.eu/pulling-cart-mirerenewed-case-european-solidarity (accessed on March 21, 2017).

Hainmueller, Jens, and Michael Hiscox. 2006. Learning to Love Globalization: Education and Individual Attitudes toward International Trade. International Organization 60 (02): 469-498.

Hainmueller, Jens, and Michael Hiscox. 2010. Attitudes toward Highly Skilled and LowSkilled Immigration: Evidence from a Survey Experiment. American Political Science Review 104 (01): 61-84.

Hainmueller, Jens, and Michael J. Hiscox. 2007. Educated Preferences: Explaining Attitudes toward Immigration in Europe. International Organization 61 (02): 399-442.

Häusermann, Silja, and Hanspeter Kriesi. 2015. What Do Voters Want? Dimensions and Configurations in Individual-Level Preferences and Party Choice. In The Politics of Advanced Capitalism, edited by Pablo Beramendi, Silja Häusermann, Herbert Kitschelt, and Hanspeter Kriesi, 202-230. Cambridge: Cambridge University Press. Hooghe, Liesbet, and Gary Marks. 2005. Calculation, Community, and Cues. European Union Politics 6 (4): 419-43.

Hooghe, Liesbet, and Gary Marks. 2009. A Postfunctionalist Theory of European Integration: From Permissive Consensus to Constraining Cissensus. British Journal of Political Science 39 (01): 1-23. 
Hooghe, Liesbet, and Gary Marks. 2017. Cleavage Theory and Europe's Crises: Lipset, Rokkan and the Transnational Cleavage, Journal of European Public Policy. Online First.

Hooghe, Liesbet, Gary Marks, and Carole J. Wilson. 2002. Does Left/Right Structure Party Positions on European Integration?. Comparative Political Studies 35 (8): 965-989. Huber, Michaela, Leaf Van Boven, A. Peter McGraw and Laura Johnson-Graham. 2011. Whom to help? Immediacy Bias in Judgments and Decisions about Humanitarian Aid. Organizational Behavior and Human Decision Processes 115 (2): 283-293. Iversen, Torben, and David Soskice. 2001. An Asset Theory of Social Policy Preferences. American Political Science Review 95 (4): 875-894.

Iversen, Torben, and David Soskice. 2006. Electoral Institutions and the Politics of Coalitions: Why Some Democracies Redistribute more than others. American Political Science Review 100 (02): 165-181.

Kitschelt, Herbert. 1994. The transformation of European social democracy. New York: Cambridge University Press.

Kitschelt, Herbert. 2004. Diversification and Reconfiguration of Party Systems in Postindustrial Democracies. Friedrich Ebert Stiftung.

Kriesi, Hanspeter, Edgar Grande, Martin Dolezal, Marc Helbling, Dominic Hoglinger, Sven Hutter, and Bruno Wuest. 2012. Political Conflict in Western Europe. Cambridge: Cambridge University Press.

Kriesi, Hanspeter, Edgar Grande, Romain Lachat, Martin Dolezal, Simon Bornschier, and Timotheus Frey. 2006. Globalization and the Transformation of the National Political Space: Six European Countries Compared. European Journal of Political Research 45 (6): 921-956.

Krugman, Paul. 2011. Can Europe be saved? New York Times, 12 January 2011. http://www.nytimes.com/2011/01/16/magazine/16Europe-t.html

Kuhn, Theresa, and Florian Stoeckel. 2014. When European Integration becomes costly. The Euro Crisis and Public Support for European Economic Governance. Journal of European Public Polics 21 (4): 624-641.

Kuhn, Theresa, Hector Solaz, and Erika van Elsas. 2017. Practicing what you preach: how cosmopolitanism promotes willingness to redistribute across the European Union. Journal of European Public Policy. Online First. 
Lengfeld, Holger, Sara Schmidt, and Julia Häuberer. 2015. Is there a European solidarity? Attitudes toward fiscal assistance for debt-ridden European Union member states. Arbeitsbericht des Instituts für Soziologie der Universität Leipzig.

Laffan, Brigid. 2016. Europe's union in crisis: tested and contested. West European Politics 39(5): 915-932.

Lewis-Beck, Michael and Mary Stegmaier. 2000. Economic determinants of electoral outcomes. Annual Review of Political Science 3 (1): 183-219.

Lumsdaine, David Halloran. 1993. Moral Vision in International Politics: The Foreign Aid Regime, 1949-1989. Princeton New Jersey: Princeton University Press.

Margalit, Yotam. 2013. Explaining Social Policy Preferences: Evidence from the Great Recession. American Political Science Review 107 (01): 80-103.

Marks, Gary and Carole Wilson. 2000. The Past in the Present: A Cleavage Theory of Party Response to European Integration. British Journal of Political Science 30 (03): 433459.

Marks, Gary, and Marco Steenbergen. 2002. Understanding Political Contestation in the European Union. Comparative Political Studies 35 (8): 879-892.

Mayda, Anna Maria. 2006. Who is Against Immigration? A Cross-country Investigation of Individual Attitudes toward Immigrants. The Review of Economics and Statistics 88 (3): $510-530$.

McLaren, Lauren M.. 2004. Opposition to European Integration and Fear of Loss of National Identity: Debunking a Basic Assumption Regarding Hostility to the Integration Project, European Journal of Political Research 43 (6): 895-911.

Meltzer, Allan H., and Scott F. Richard. 1981. A Rational Theory of the Size of Government. The Journal of Political Economy 89 (5): 914-927.

Moravcsik, Andrew. 1998. The Choice for Europe: Social Purpose and State Power from Messina to Maastricht (Vol. 1). Ithaca, NY: Cornell University Press.

Noël, Alain, and Jean-Phillipe Thérien. 2002. Public Opinion and Global Justice. Comparative Political Studies 35(6): 631-656.

Oesch, Daniel. 2006. Redrawing the Class Map: Stratification and Institutions in Britain, Germany, Sweden and Switzerland. London: Palgrave Macmillan.

Petersen, Michael Band, Rune Slothuus, Rune Stubager, and Lise Togeby. 2011.

Deservingness versus Values in Public Opinion on Welfare: The Automaticity of the Deservingness Heuristic. European Journal of Political Research 50 (1): 24-52. 
Piketty, Thomas. 1995. Social Mobility and Redistributive Politics. The Quarterly Journal of Economics 110 (3): 551-584.

Rehm, Philipp. 2009. Risks and Redistribution an Individual-level Analysis. Comparative Political Studies 42 (7): 855-881.

Risse, Thomas. 2010. A Community of Europeans? Transnational Identities and Public Sphere, Ithaca, NY: Cornell University Press.

Rueda, David, and Daniel Stegmueller. 2016. Who Wants Want? Redistribution Preferences in Comparative Perspective. Book Manuscript presented at the Workshop “Preferences over Redistribution”, Duke University, April 29-30, 2016.

Scheve, Kenneth F., and Matthew J. Slaughter. 2001a. Labor Market Competition and Individual Preferences over Immigration Policy. Review of Economics and Statistics 83 (1): $133-145$.

Scheve, Kenneth F., and Matthew J. Slaughter. 2001b. What Determines Individual TradePolicy Preferences?. Journal of International Economics 54 (2): 267-292.

Schmitt, Hermann, Sebastian A. Popa, Sara B. Hobolt, and Eftichia Teperoglou. 2015. European Parliament Election Study 2014, Voter Study. GESIS Data Archive, ZA5160, doi:10.4232/1.5160.

Sniderman, Paul M., Louk Hagendoorn, and Markus Prior. 2004. Predispositional Factors and Situational Triggers: Exclusionary Reactions to Immigrant Minorities. American Political Science Review 98 (1): 35-50.

Steenbergen, Marco R., and Bradford S. Jones. 2002. Modeling Multilevel Data Structures. American Journal of Political Science 46 (1): 218-237.

Stoeckel, Florian and Theresa Kuhn. 2017. Mobilizing Citizens for Costly Policies: the Conditional Effect of Party Cues on Support for International Bailouts in the European Union. JCMS: Journal of Common Market Studies. Online First.

Svallfors, Stefan. 2004. Class, Attitudes and the Welfare state: Sweden in Comparative Perspective. Social policy \& Administration 38 (2): 119-138.

Verhaegen, Soetkin. 2017. What to expect from European identity? Explaining support for solidarity in times of crisis. Comparative European Politics. Online First 
Table 1: Multilevel model, determinants of support for EU transfers

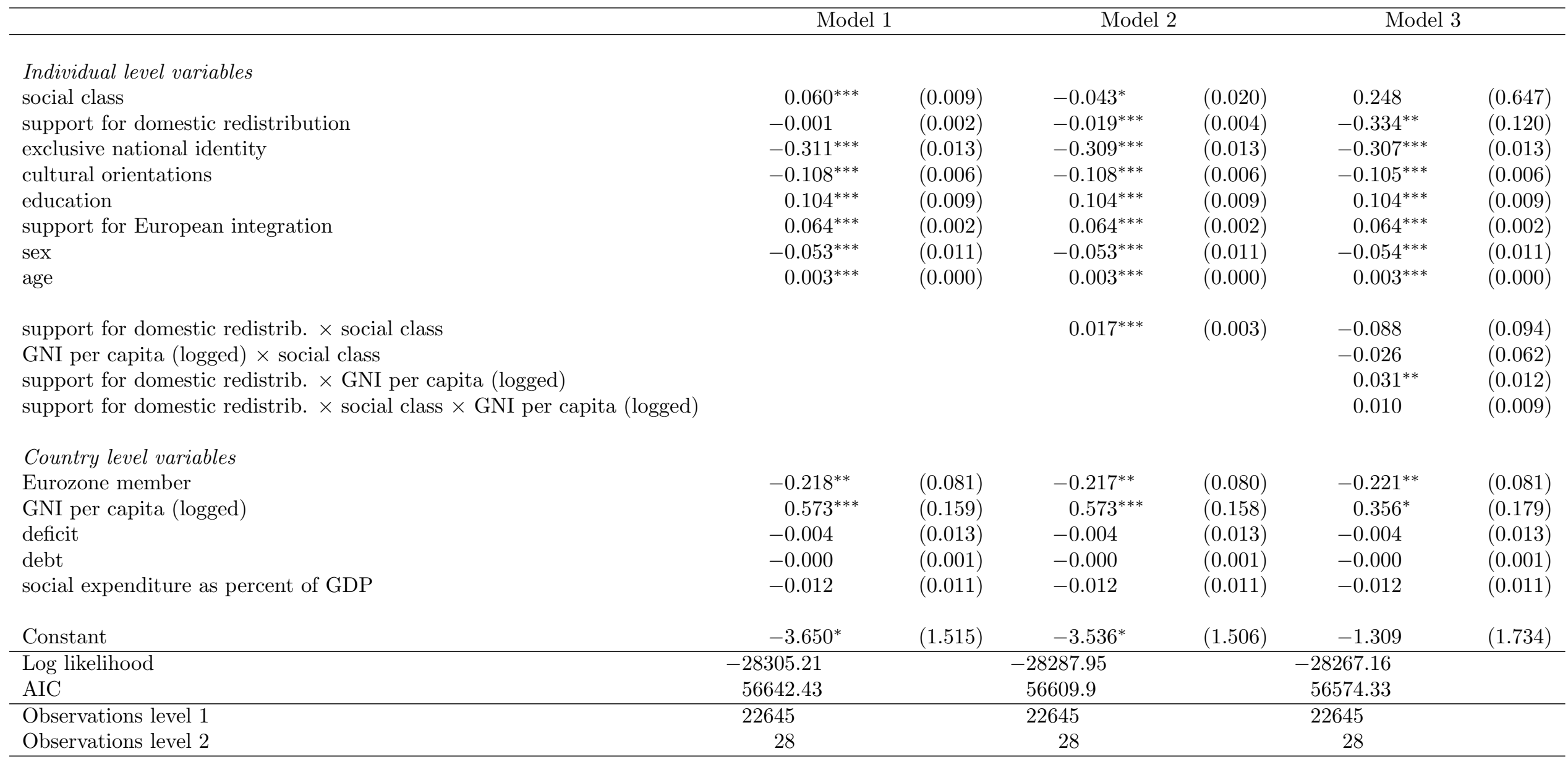

Standard errors in parentheses, ${ }^{*} p<0.05,{ }^{* *} p<0.01,{ }^{* * *} p<0.001$

reference categories: inclusive national identity, male, non Eurozone countries 
Table 2: Multilevel model, determinants of support for EU transfers (alternative measures for social class)

\begin{tabular}{|c|c|c|c|c|c|c|}
\hline \multirow{2}{*}{ Individual level variables } & \multicolumn{2}{|c|}{ Model 1} & \multicolumn{2}{|c|}{ Model 2} & \multicolumn{2}{|c|}{ Model 3} \\
\hline & & & & & & \\
\hline support for domestic redistribution & $-0.022^{* * *}$ & $(0.004)$ & $-0.021^{* * *}$ & $(0.005)$ & $-0.033^{* *}$ & $(0.012)$ \\
\hline education & 0.023 & $(0.019)$ & $0.113^{* * *}$ & $(0.009)$ & $0.082^{* * *}$ & $(0.013)$ \\
\hline support for domestic redistrib. $\times$ education & $0.015^{* * *}$ & $(0.003)$ & & & & \\
\hline financial standing & & & -0.037 & $(0.020)$ & & \\
\hline support for domestic redistrib. $\times$ financial standing & & & $0.012^{* * *}$ & $(0.003)$ & & \\
\hline unemployed & & & & & -0.065 & $(0.102)$ \\
\hline skilled labor & & & & & -0.144 & $(0.094)$ \\
\hline small business owners & & & & & -0.160 & $(0.110)$ \\
\hline employed professionals & & & & & 0.020 & $(0.111)$ \\
\hline middle management & & & & & -0.112 & $(0.102)$ \\
\hline self-employed professionals and managers & & & & & -0.179 & $(0.103)$ \\
\hline support for domestic redistrib. $\times$ unemployed & & & & & 0.019 & $(0.014)$ \\
\hline support for domestic redistrib. $\times$ skilled labor & & & & & $0.032^{*}$ & $(0.013)$ \\
\hline support for domestic redistrib. $\times$ small business owners & & & & & $0.034^{*}$ & $(0.015)$ \\
\hline support for domestic redistrib. $\times$ employed professionals & & & & & 0.018 & $(0.016)$ \\
\hline support for domestic redistrib. $\times$ middle management & & & & & $0.048^{* * *}$ & $(0.014)$ \\
\hline support for domestic redistrib. $\times$ self-employed professionals and managers & & & & & $0.059^{* * *}$ & $(0.015)$ \\
\hline exclusive national identity & $-0.317^{* * *}$ & $(0.013)$ & $-0.310^{* * *}$ & $(0.013)$ & $-0.312^{* * *}$ & $(0.017)$ \\
\hline cultural openness & $-0.108^{* * *}$ & $(0.006)$ & $-0.107^{* * *}$ & $(0.006)$ & $-0.109^{* * *}$ & $(0.008)$ \\
\hline $\operatorname{sex}$ & $-0.052^{* * *}$ & $(0.011)$ & $-0.049^{* * *}$ & $(0.011)$ & $-0.045^{* *}$ & $(0.015)$ \\
\hline age & $0.003^{* * *}$ & $(0.000)$ & $0.003^{* * *}$ & $(0.000)$ & $0.002^{* *}$ & $(0.001)$ \\
\hline support for European integration & $0.066^{* * *}$ & $(0.002)$ & $0.065^{* * *}$ & $(0.002)$ & $0.069^{* * *}$ & $(0.003)$ \\
\hline \multicolumn{7}{|l|}{ Country level variables } \\
\hline Eurozone member & $-0.221^{* *}$ & $(0.082)$ & $-0.219^{* *}$ & $(0.082)$ & $-0.261^{* * *}$ & $(0.018)$ \\
\hline GNI per capita (logged) & $0.612^{* * *}$ & $(0.161)$ & $0.593^{* * *}$ & $(0.160)$ & $0.680^{* * *}$ & $(0.038)$ \\
\hline deficit & -0.005 & $(0.013)$ & -0.005 & $(0.013)$ & $-0.012^{* * *}$ & $(0.003)$ \\
\hline debt & -0.000 & $(0.001)$ & -0.000 & $(0.001)$ & -0.001 & $(0.000)$ \\
\hline social expenditure as percent of GDP & -0.013 & $(0.012)$ & -0.013 & $(0.012)$ & $-0.012^{* * *}$ & $(0.003)$ \\
\hline Constant & $-3.869^{*}$ & $(1.539)$ & $-3.736^{*}$ & $(1.530)$ & $-4.488^{* * *}$ & $(0.377)$ \\
\hline Log Likelihood & -28841.06 & & -28488 & & -16851.53 & \\
\hline AIC & 57714.12 & & 57010 & & 33755.06 & \\
\hline Observations level 1 & 23047 & & 22780 & & 13419 & \\
\hline Observations level 2 & 28 & & 28 & & 28 & \\
\hline
\end{tabular}

Standard errors in parentheses, ${ }^{*} p<0.05,{ }^{* *} p<0.01,{ }^{* * *} p<0.001$

reference categories: inclusive national identity, male, non Eurozone countries, occupation: unskilled labor 


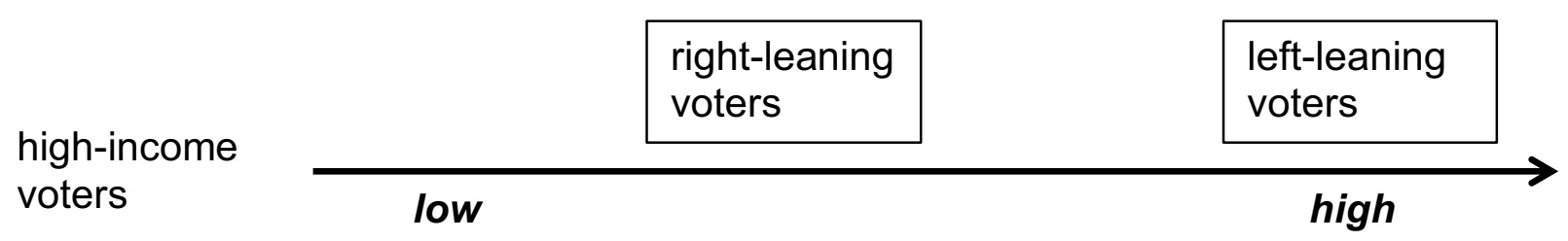

level of support for EU transfers

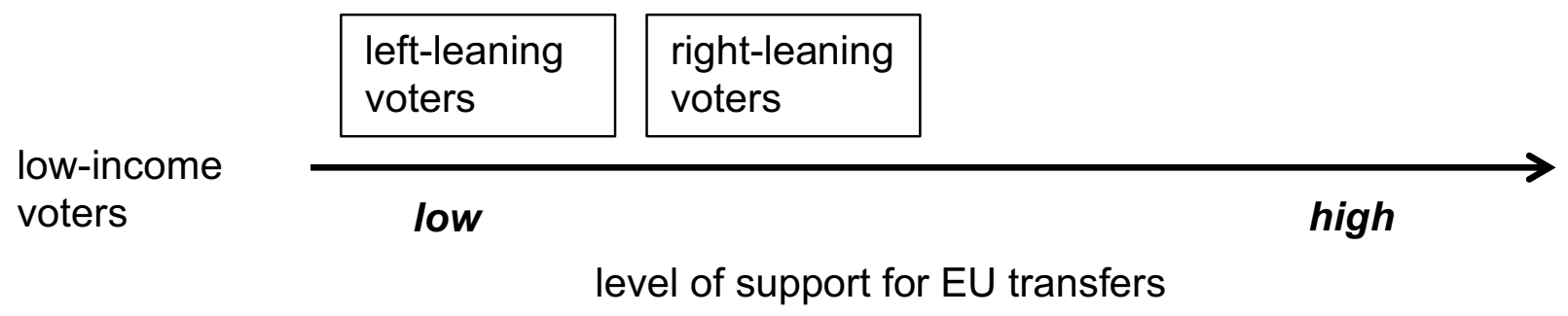

Figure 1: Theory regarding preferences for EU transfers 


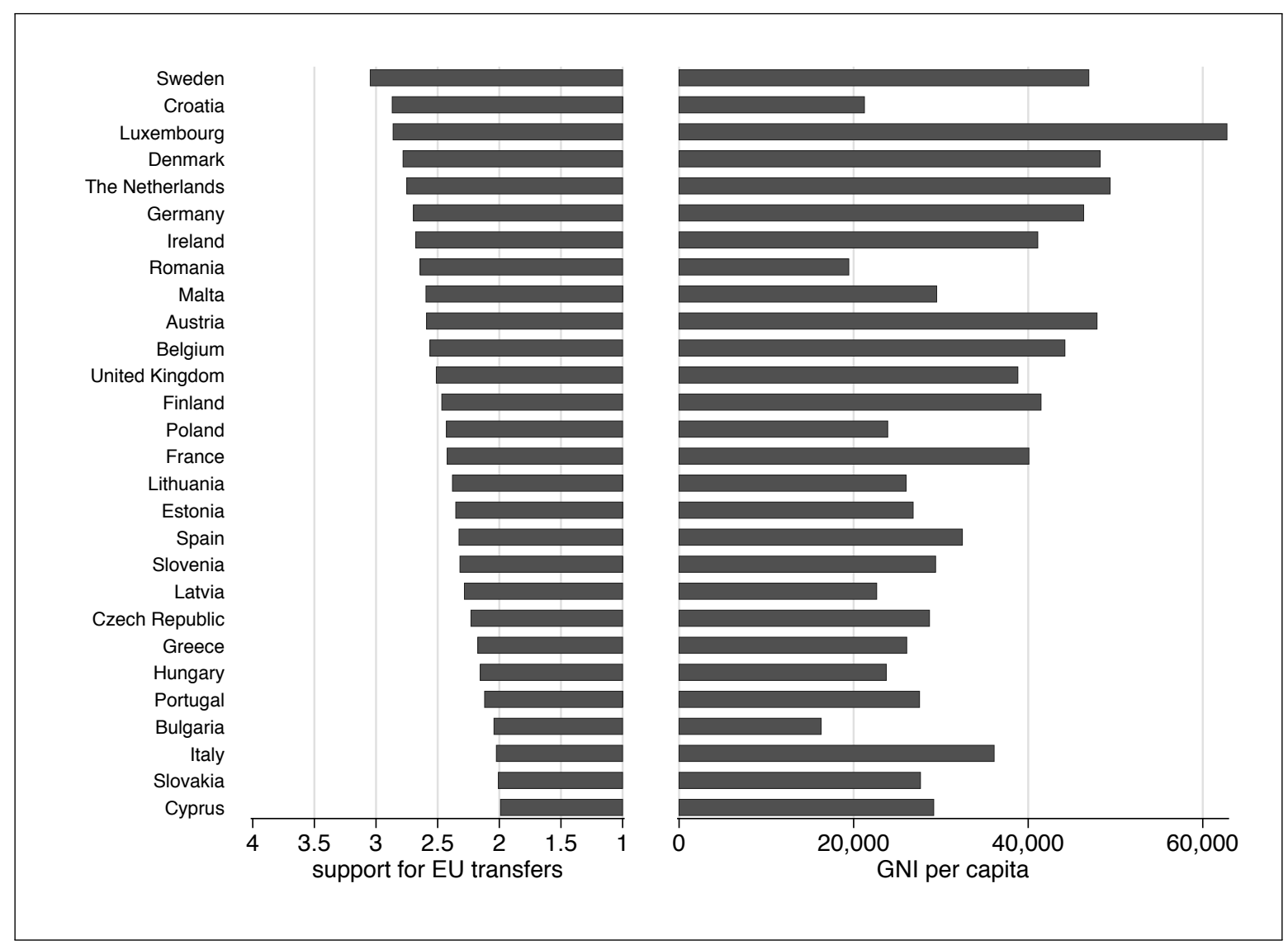

Figure 2: Mean support for EU transfers and GNI per capita by country 


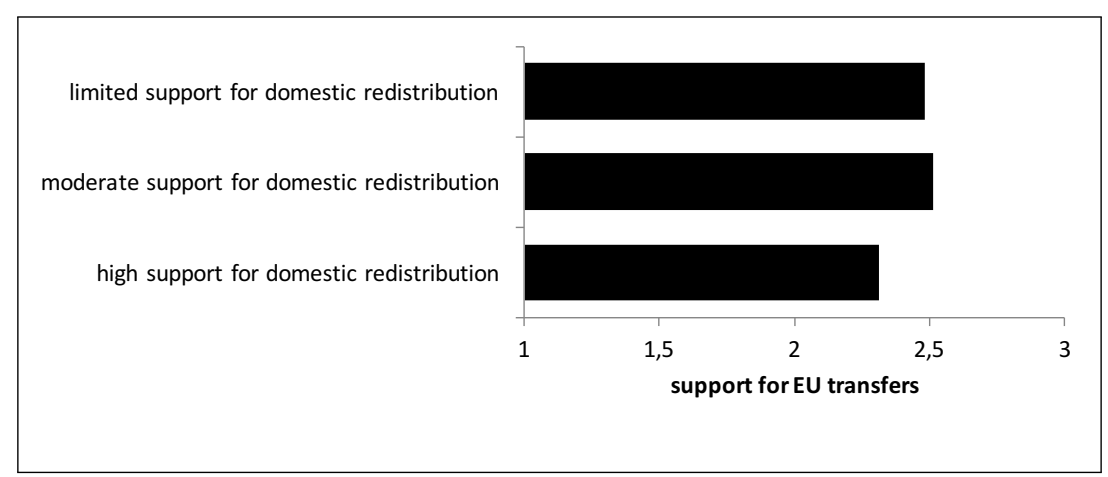

Figure 3: Support for EU transfers by levels of support for domestic redistribution

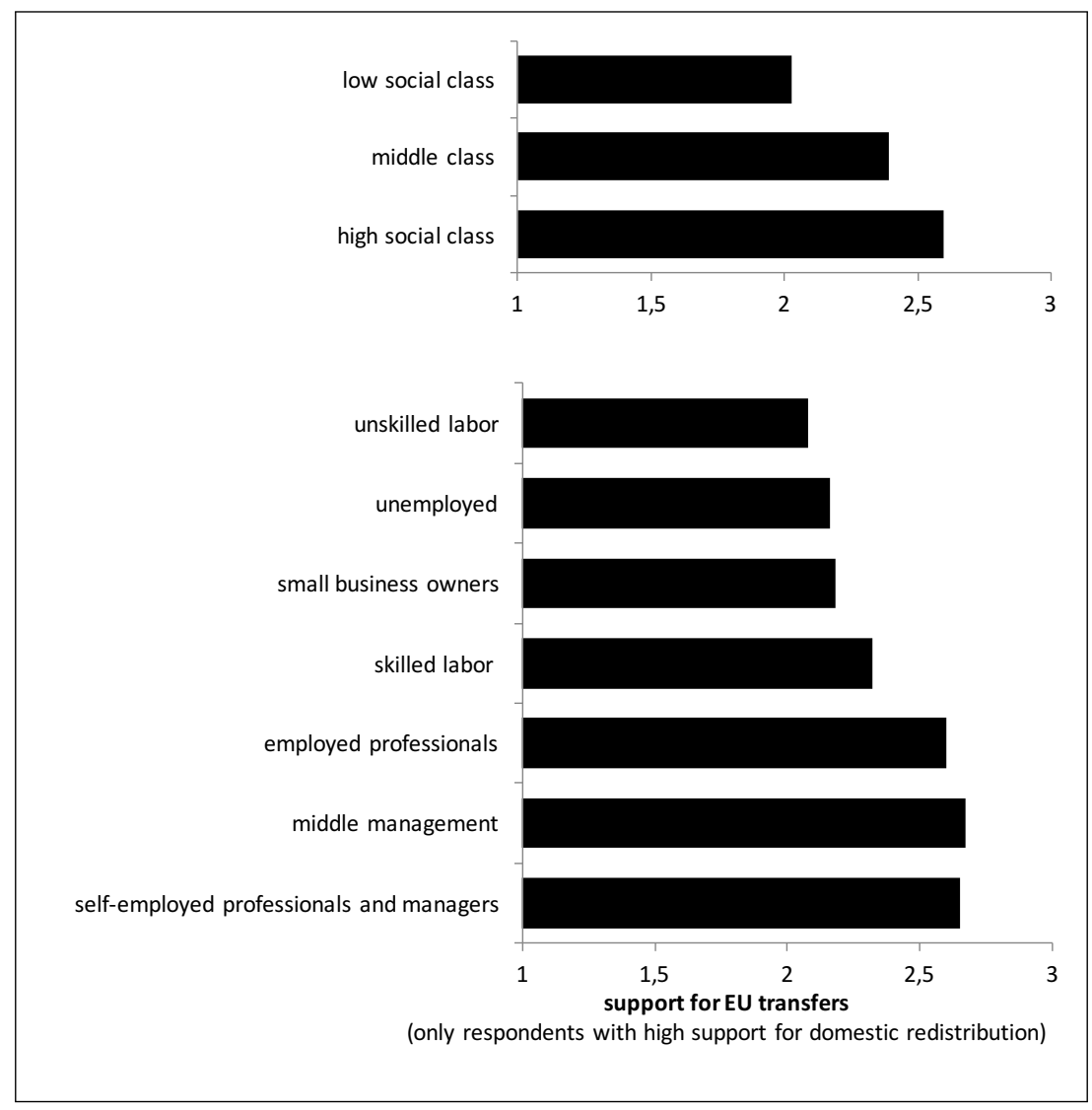

Figure 4: Support for EU transfers by class and occupation (only respondents with high support for domestic redistribution, i.e. left leaning voters) 


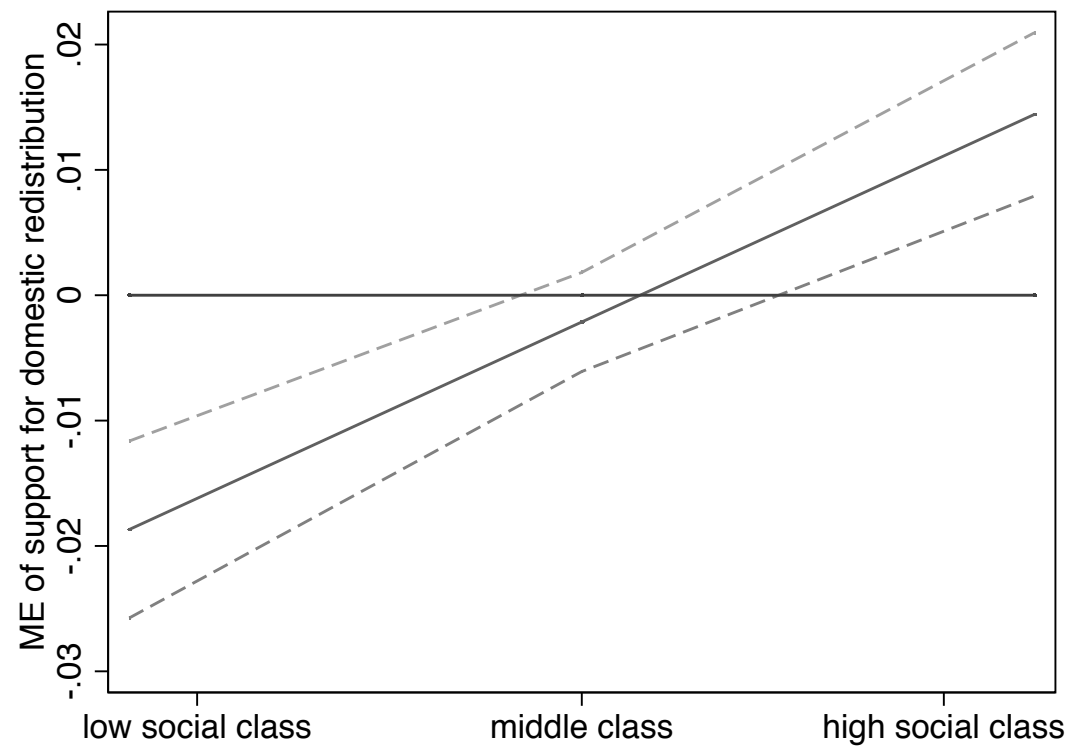

Figure 5: Marginal effect of support for domestic redistribution on EU transfers by social class

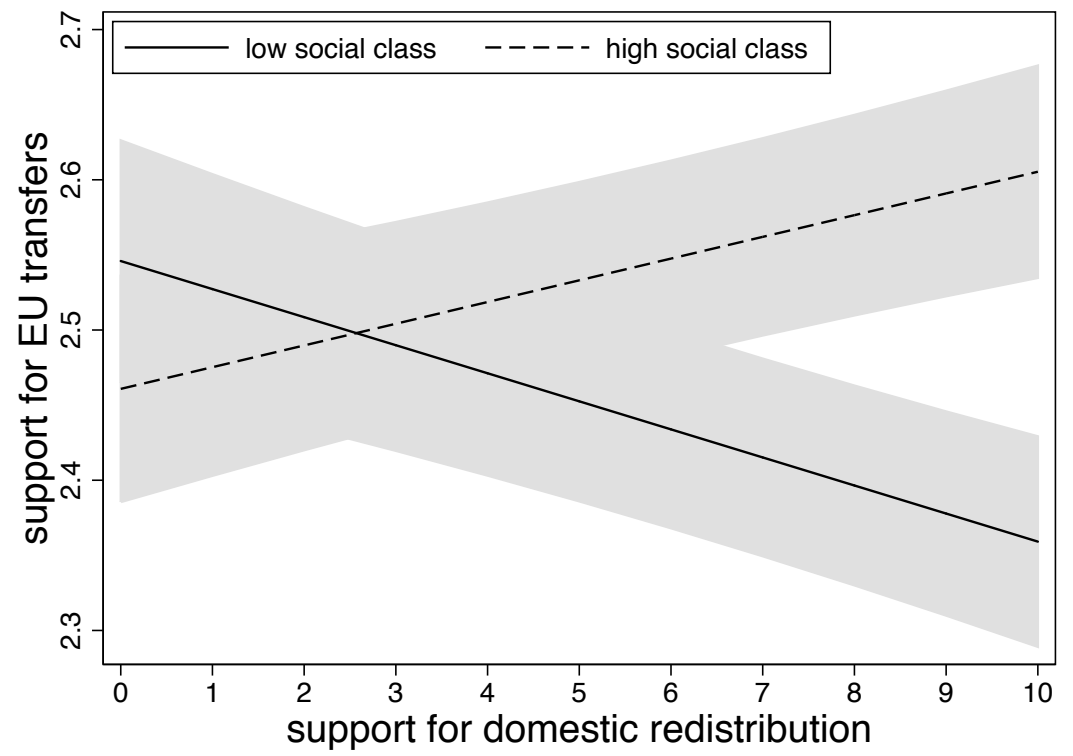

Figure 6: Support for EU transfers by social class (two-way interaction) 
(a) Marginal effect of a 2 SD change in support for domestic redistribution for different social classes

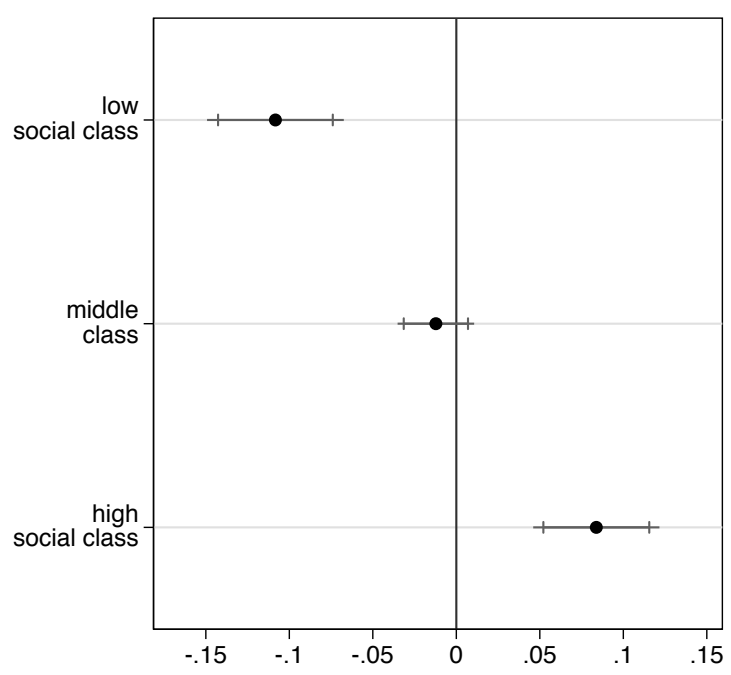

(c) Marginal effect of a 2 SD change in support for domestic redistribution for different levels of financial standing

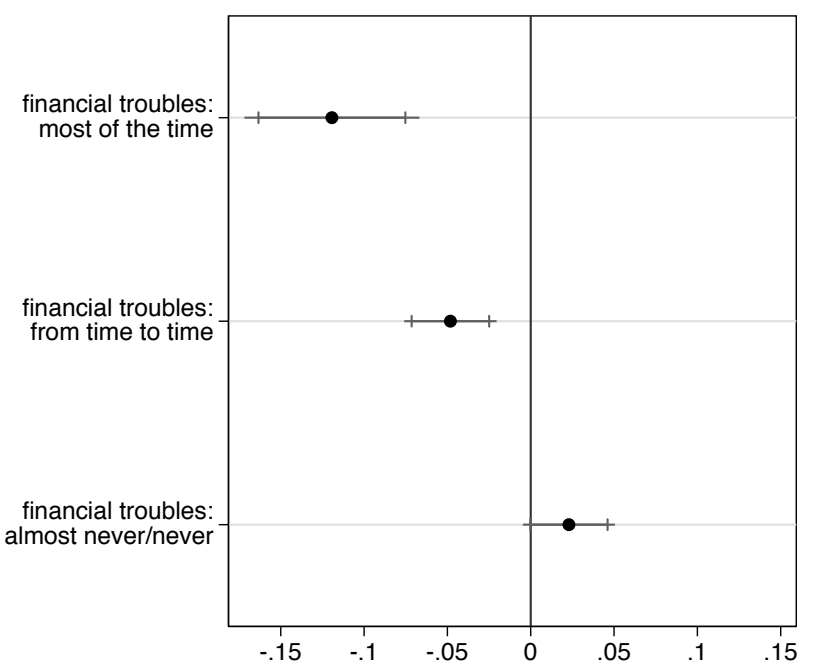

(b) Marginal effect of a 2 SD change in support for domestic redistribution for different levels of education

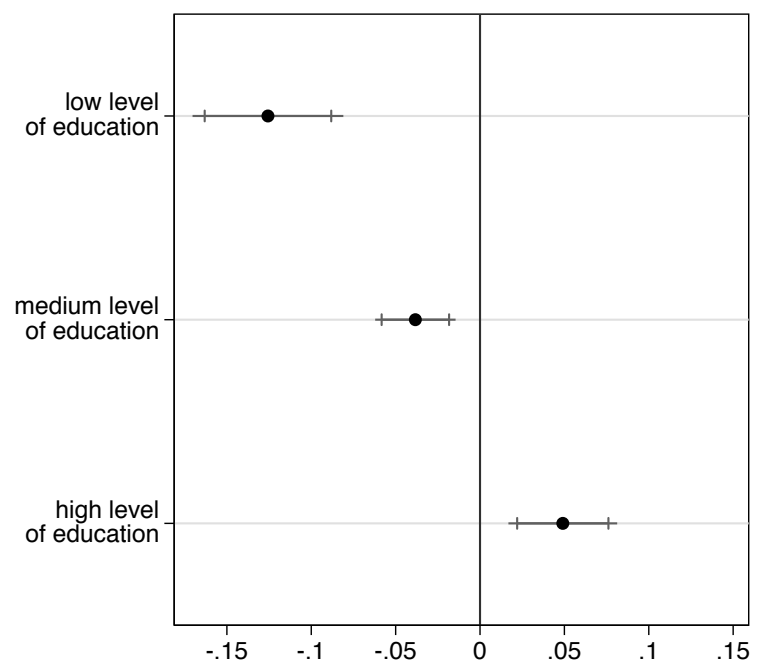

(d) Marginal effect of a 2 SD change in support for domestic redistribution for different occupational groups

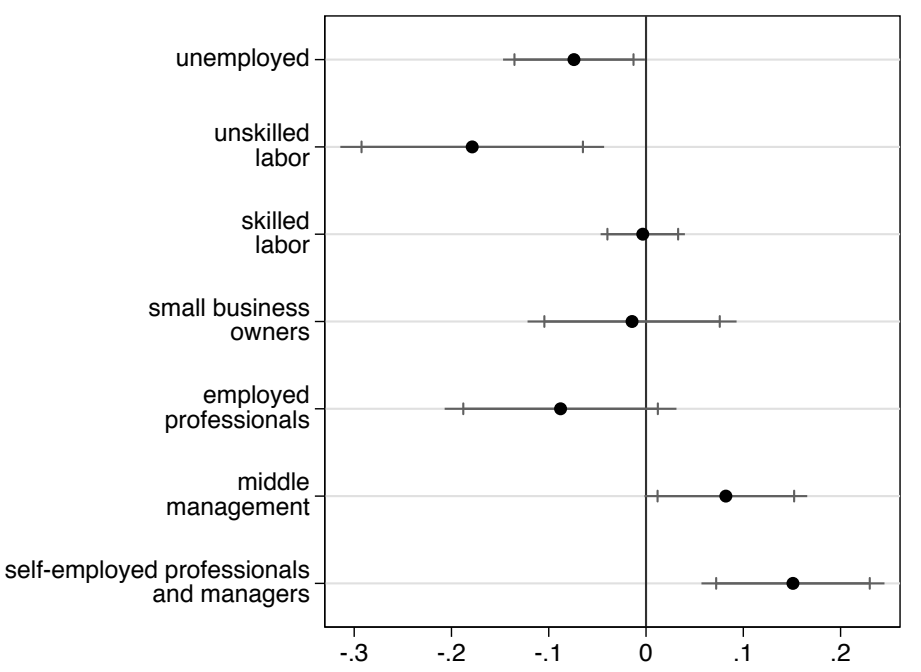

Figure 7: Marginal effects of a two standard deviation change in support for domestic redistribution by social class, education, financial standing, and occupation. Horizontal lines represent 95 percent confidence intervals and spikes represent 90 percent confidence intervals. 


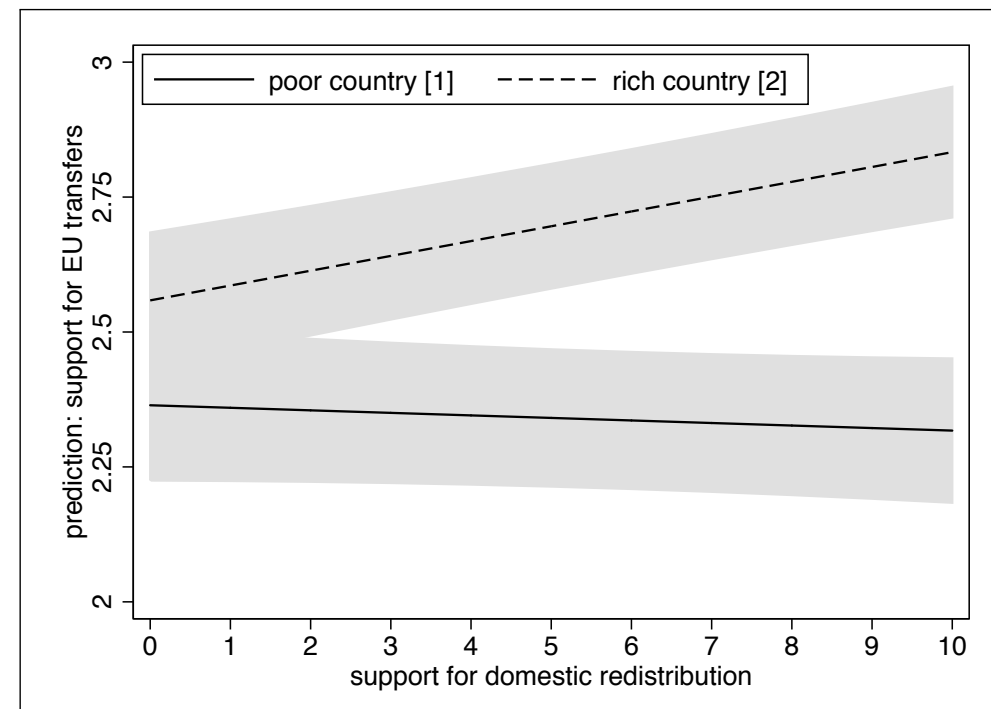

(a) prediction for high social class

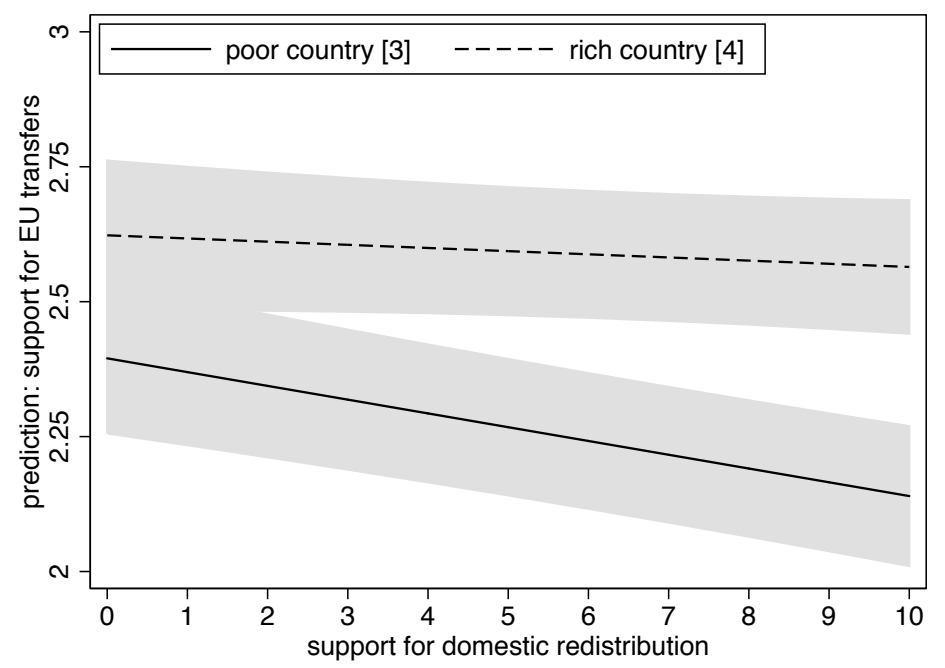

(b) prediction for low social class

Figure 8: Support for EU transfers by social class and GNI per capita (three-way interaction) 


\section{Online Appendix A}

Table A1: Descriptive statistics

\begin{tabular}{lccccc}
\hline variable & count & mean & sd & min & max \\
\hline support for EU transfers & 28796 & 2.45 & 0.95 & 1 & 4 \\
social class & 29220 & 1.01 & 0.69 & 0 & 2 \\
support for domestic redistribution & 28483 & 6.23 & 2.93 & 0 & 10 \\
exclusive national identity (ref.: inclusive nat. identity) & 29624 & 0.33 & - & 0 & 1 \\
cultural orientations & 26226 & 0.00 & 1.08 & -2.83 & 2.52 \\
education & 29511 & 1.22 & 0.73 & 0 & 2 \\
financial standing & 29523 & 1.49 & 0.70 & 0 & 2 \\
occupation, total of respondents in the following groups: & 17020 & & & & \\
unemployed & 2760 & 0.16 & - & 0 & 1 \\
unskilled labor & 909 & 0.5 & - & 0 & 1 \\
skilled labor & 7928 & 0.47 & - & 0 & 1 \\
small business owners & 1151 & 0.06 & - & 0 & 1 \\
employed professionals & 892 & 0.05 & - & 0 & 1 \\
middle management & 2037 & 0.12 & - & 0 & 1 \\
self-employed professionals and managers & 1343 & 0.07 & - & 0 & 1 \\
sex (ref.: male) & 30064 & 0.55 & - & 0 & 1 \\
age & 30064 & 51.06 & 17.92 & 16 & 99 \\
EU support & 27362 & 4.66 & 3.11 & 0 & 10 \\
GNI p.c. in PPP & 30064 & 33960.07 & 10626.53 & 16280 & 62780 \\
GDP p.c. in PPP & 30064 & 25452.66 & 9197.29 & 11900 & 70100 \\
Deficit & 30064 & -3.52 & 3.44 & -14.90 & 0.90 \\
Debt & 30064 & 72.41 & 36.73 & 10.10 & 175.00 \\
Social expenditure as percent of GDP & 30064 & 17.29 & 4.13 & 11.30 & 25.10 \\
net contributions 2013 as percent of GNI & 30064 & 0.01 & 0.02 & -0.01 & 0.06 \\
\hline
\end{tabular}


Table A2: Analysis of three-way interaction effects following Dawson and Richter (2006)

\begin{tabular}{lll}
\hline & $\begin{array}{c}\text { slope } \\
\text { difference }\end{array}$ & $\begin{array}{c}\text { standard } \\
\text { error }\end{array}$ \\
\hline $\begin{array}{l}\text { Low class in poor country vs } \\
\text { Low class in rich country }\end{array}$ & $-0.020^{*}$ & 0.007 \\
\hline $\begin{array}{l}\text { High class in rich country vs } \\
\text { Low class in rich country }\end{array}$ & $0.033^{* * *}$ & 0.008 \\
\hline $\begin{array}{l}\text { High class in poor country vs } \\
\text { Low class in rich country }\end{array}$ & 0.001 & 0.008 \\
\hline $\begin{array}{l}\text { High class in rich country vs } \\
\text { Low class in poor country }\end{array}$ & $0.053^{* * *}$ & 0.006 \\
\hline $\begin{array}{l}\text { High class in poor country vs } \\
\text { Low class in poor country }\end{array}$ & $0.021^{* *}$ & 0.008 \\
\hline $\begin{array}{l}\text { High class in poor country vs } \\
\text { Low class in poor country }\end{array}$ & $-0.032^{* * *}$ \\
\hline \hline rich country: GNI p.c. 1 sd above mean, poor country: GNI p.c. 1 sd below mean, \\
low social class: class $=0$, high social class: class=2 \\
$* p<0.05, * * p 0.01, * * *<0.001$
\end{tabular}


Table A3: multilevel ordered logit regression results, determinants of support for EU transfers

\begin{tabular}{|c|c|c|c|c|c|c|}
\hline \multirow[b]{2}{*}{ social class } & \multicolumn{2}{|c|}{ Model 1} & \multicolumn{2}{|c|}{ Model 2} & \multicolumn{2}{|c|}{ Model 3} \\
\hline & $0.138^{* * *}$ & $(0.020)$ & $-0.113^{*}$ & $(0.044)$ & 0.560 & $(1.379)$ \\
\hline support for domestic redistribution & 0.000 & $(0.005)$ & $-0.043^{* * *}$ & $(0.008)$ & $-0.675^{* *}$ & $(0.259)$ \\
\hline exclusive national identity & $-0.668^{* * *}$ & $(0.029)$ & $-0.664^{* * *}$ & $(0.029)$ & $-0.662^{* * *}$ & $(0.029)$ \\
\hline cultural orientations & $-0.245^{* * *}$ & $(0.013)$ & $-0.244^{* * *}$ & $(0.013)$ & $-0.240^{* * *}$ & $(0.013)$ \\
\hline education & $0.231^{* * *}$ & $(0.020)$ & $0.230^{* * *}$ & $(0.020)$ & $0.231^{* * *}$ & $(0.020)$ \\
\hline $\operatorname{sex}$ & $-0.122^{* * *}$ & $(0.025)$ & $-0.124^{* * *}$ & $(0.025)$ & $-0.124^{* * *}$ & $(0.025)$ \\
\hline age & $0.007^{* * *}$ & $(0.001)$ & $0.007^{* * *}$ & $(0.001)$ & $0.007^{* * *}$ & $(0.001)$ \\
\hline support for European integration & $0.152^{* * *}$ & $(0.005)$ & $0.151^{* * *}$ & $(0.005)$ & $0.151^{* * *}$ & $(0.005)$ \\
\hline Eurozone member & $-0.493^{* *}$ & $(0.181)$ & $-0.492^{* *}$ & $(0.181)$ & $-0.501^{* *}$ & $(0.182)$ \\
\hline GDP p.c. (logged) & $1.038^{* * *}$ & $(0.294)$ & $1.037^{* * *}$ & $(0.293)$ & 0.612 & $(0.344)$ \\
\hline deficit & -0.002 & $(0.028)$ & -0.002 & $(0.028)$ & -0.003 & $(0.028)$ \\
\hline debt & 0.000 & $(0.003)$ & 0.000 & $(0.003)$ & 0.000 & $(0.003)$ \\
\hline social expenditure as percent of GDP & -0.011 & $(0.023)$ & -0.011 & $(0.023)$ & -0.010 & $(0.023)$ \\
\hline social class $\times$ support for domestic redistrib. & & & $0.041^{* * *}$ & $(0.006)$ & -0.152 & $(0.202)$ \\
\hline support for domestic redistrib. $\times$ GDP p.c. (logged) & & & & & $0.063^{*}$ & $(0.026)$ \\
\hline social class $\times$ GDP p.c. (logged) & & & & & -0.063 & $(0.137)$ \\
\hline support for domestic redistrib. $\times$ social class $\times$ GDP p.c. $($ logged $)$ & & & & & 0.018 & $(0.020)$ \\
\hline \multicolumn{7}{|l|}{ cut1 } \\
\hline Constant & $9.559^{* * *}$ & $(2.740)$ & $9.275^{* * *}$ & $(2.729)$ & 5.046 & $(3.272)$ \\
\hline \multicolumn{7}{|l|}{ cut2 } \\
\hline Constant & $11.040^{* * *}$ & $(2.740)$ & $10.758^{* * *}$ & $(2.729)$ & $6.531^{*}$ & $(3.272)$ \\
\hline \multicolumn{7}{|l|}{ cut3 } \\
\hline Constant & $13.482^{* * *}$ & $(2.741)$ & $13.201^{* * *}$ & $(2.730)$ & $8.977^{* *}$ & $(3.272)$ \\
\hline Observations level 1 & 22645 & & 22645 & & 22645 & \\
\hline Observations level 2 & 28 & & 28 & & 28 & \\
\hline
\end{tabular}

Standard errors in parentheses

${ }^{*} p<0.05,{ }^{* *} p<0.01,{ }^{* * *} p<0.001$ 
Table A4: coding of occupations based on Oesch (2006)

\begin{tabular}{ll}
\hline \hline Occupational category & European Election Study occupational category \\
\hline Category Unemployed & 3) Unemployed \\
\hline Category Unskilled labor & $\begin{array}{l}\text { 18) Unskilled workers, low-skilled production work- } \\
\text { ers }\end{array}$ \\
\hline Category Skilled labor & $\begin{array}{l}\text { 13) Employed (working at desk) 15) Employed (not } \\
\text { working at desk but in service) 16) Supervisor or } \\
\text { skilled craft worker 17) Skilled manual worker 14) } \\
\text { Employed (not at a desk but travelling) }\end{array}$ \\
\hline Category Small business owners & 5) Farmer 6) Fisherman 8) Owner of a small shop \\
\hline Category Employed professionals & 10) Employed professionals \\
\hline Category Middle management & 12) Semi-professionals and associate managers \\
\hline Category Self-employed professionals & 9) Business proprietors 7) Self-employed profession- \\
and managers & als 11) General management (large employers, self- \\
\hline \hline
\end{tabular}

Numbers refer to occupational codes of the EES 2014 data set, excluded: 1) Houseperson; Responsible for shopping, etc.,

2) Student, 4) Retired, explains loss of $\mathrm{N}=10000$, use of previous occupation: more missing data and unreliable estimates. 
Table A5: Multilevel model, determinants of support for EU transfers; robustness check: additionally controlling for net contributions to the EU budget

\begin{tabular}{|c|c|c|c|c|c|c|}
\hline \multirow[b]{2}{*}{ support for domestic redistribution } & \multicolumn{2}{|c|}{ Model 1} & \multicolumn{2}{|c|}{ Model 2} & \multicolumn{2}{|c|}{ Model 3} \\
\hline & -0.001 & $(0.002)$ & $-0.019^{* * *}$ & $(0.004)$ & $-0.290^{*}$ & $(0.113)$ \\
\hline social class & $0.060^{* * *}$ & $(0.009)$ & $-0.043^{*}$ & $(0.020)$ & 0.169 & $(0.611)$ \\
\hline GDP p.c. (logged) & $0.335^{*}$ & $(0.143)$ & $0.335^{*}$ & $(0.143)$ & 0.135 & $(0.163)$ \\
\hline exclusive national identity & $-0.311^{* * *}$ & $(0.013)$ & $-0.309^{* * *}$ & $(0.013)$ & $-0.308^{* * *}$ & $(0.013)$ \\
\hline cultural orientations & $-0.108^{* * *}$ & $(0.006)$ & $-0.107^{* * *}$ & $(0.006)$ & $-0.106^{* * *}$ & $(0.006)$ \\
\hline education & $0.104^{* * *}$ & $(0.009)$ & $0.104^{* * *}$ & $(0.009)$ & $0.104^{* * *}$ & $(0.009)$ \\
\hline $\operatorname{sex}$ & $-0.052^{* * *}$ & $(0.011)$ & $-0.053^{* * *}$ & $(0.011)$ & $-0.053^{* * *}$ & $(0.011)$ \\
\hline age & $0.003^{* * *}$ & $(0.000)$ & $0.003^{* * *}$ & $(0.000)$ & $0.003^{* * *}$ & $(0.000)$ \\
\hline support for European integration & $0.064^{* * *}$ & $(0.002)$ & $0.064^{* * *}$ & $(0.002)$ & $0.064^{* * *}$ & $(0.002)$ \\
\hline Eurozone member & $-0.236^{* *}$ & $(0.075)$ & $-0.235^{* *}$ & $(0.075)$ & $-0.239^{* *}$ & $(0.075)$ \\
\hline deficit & -0.004 & $(0.012)$ & -0.004 & $(0.012)$ & -0.004 & $(0.012)$ \\
\hline debt & -0.000 & $(0.001)$ & -0.000 & $(0.001)$ & -0.000 & $(0.001)$ \\
\hline social expenditure as percent of GDP & -0.010 & $(0.010)$ & -0.010 & $(0.010)$ & -0.010 & $(0.010)$ \\
\hline net contributions 2013 as percent of GNI & -5.102 & $(2.663)$ & -5.083 & $(2.649)$ & $-5.225^{*}$ & $(2.662)$ \\
\hline support for domestic redistrib. $\times$ social class & & & $0.017^{* * *}$ & $(0.003)$ & -0.071 & $(0.089)$ \\
\hline support for domestic redistrib. $\times$ GDP p.c. (logged) & & & & & $0.027^{*}$ & $(0.011)$ \\
\hline social class $\times$ GDP p.c. (logged) & & & & & -0.019 & $(0.061)$ \\
\hline support for domestic redistrib. $\times$ social class $\times$ GDP p.c. $($ logged $)$ & & & & & 0.008 & $(0.009)$ \\
\hline Constant & -1.016 & $(1.425)$ & -0.901 & $(1.417)$ & 1.094 & $(1.624)$ \\
\hline Observations level 1 & 22645 & & 22645 & & 22645 & \\
\hline Observations level 2 & 28 & & 28 & & 28 & \\
\hline
\end{tabular}

Standard errors in parentheses

${ }^{*} p<0.05,{ }^{* *} p<0.01,{ }^{* * *} p<0.001$ 
Table A6: Multilevel model, determinants of support for EU transfers; robustness check: only member states of the Eurozone

\begin{tabular}{|c|c|c|c|c|c|c|}
\hline \multirow[b]{2}{*}{ social class } & \multicolumn{2}{|c|}{ Model 1} & \multicolumn{2}{|c|}{ Model 2} & \multicolumn{2}{|c|}{ Model 3} \\
\hline & $0.055^{* * *}$ & $(0.011)$ & -0.014 & $(0.026)$ & 0.165 & $(0.864)$ \\
\hline support for domestic redistribution & -0.001 & $(0.003)$ & $-0.013^{* *}$ & $(0.005)$ & -0.279 & $(0.166)$ \\
\hline exclusive national identity & $-0.335^{* * *}$ & $(0.017)$ & $-0.334^{* * *}$ & $(0.017)$ & $-0.333^{* * *}$ & $(0.017)$ \\
\hline cultural orientations & $-0.118^{* * *}$ & $(0.008)$ & $-0.117^{* * *}$ & $(0.008)$ & $-0.116^{* * *}$ & $(0.008)$ \\
\hline education & $0.123^{* * *}$ & $(0.011)$ & $0.123^{* * *}$ & $(0.011)$ & $0.123^{* * *}$ & $(0.011)$ \\
\hline $\operatorname{sex}$ & $-0.086^{* * *}$ & $(0.014)$ & $-0.087^{* * *}$ & $(0.014)$ & $-0.087^{* * *}$ & $(0.014)$ \\
\hline age & $0.004^{* * *}$ & $(0.000)$ & $0.004^{* * *}$ & $(0.000)$ & $0.004^{* * *}$ & $(0.000)$ \\
\hline support for European integration & $0.066^{* * *}$ & $(0.002)$ & $0.066^{* * *}$ & $(0.002)$ & $0.066^{* * *}$ & $(0.002)$ \\
\hline GDP p.c. (logged) & $0.429^{* * *}$ & $(0.123)$ & $0.429^{* * *}$ & $(0.123)$ & 0.251 & $(0.165)$ \\
\hline deficit & 0.004 & $(0.010)$ & 0.004 & $(0.010)$ & 0.003 & $(0.010)$ \\
\hline debt & -0.000 & $(0.001)$ & -0.000 & $(0.001)$ & -0.000 & $(0.001)$ \\
\hline social expenditure as percent of GDP & -0.004 & $(0.009)$ & -0.004 & $(0.009)$ & -0.004 & $(0.009)$ \\
\hline social class $\times$ support for domestic redistrib. & & & $0.011^{* *}$ & $(0.004)$ & -0.062 & $(0.127)$ \\
\hline support for domestic redistrib. $\times$ GDP p.c. (logged) & & & & & 0.026 & $(0.016)$ \\
\hline social class $\times$ GDP p.c. $($ logged $)$ & & & & & -0.017 & $(0.085)$ \\
\hline support for domestic redistrib. $\times$ social class $\times$ GDP p.c. $($ logged $)$ & & & & & 0.007 & $(0.013)$ \\
\hline Constant & $-2.370^{*}$ & $(1.197)$ & -2.296 & $(1.195)$ & -0.501 & $(1.638)$ \\
\hline Observations level 1 & 14439 & & 14439 & & 14439 & \\
\hline Observations level 2 & 18 & & 18 & & 18 & \\
\hline
\end{tabular}

Standard errors in parentheses

${ }^{*} p<0.05,{ }^{* *} p<0.01,{ }^{* * *} p<0.001$ 
Table A7: Multilevel model, determinants of support for EU transfers; robustness check: model based on European Stability Mechanism (ESM) members that did not receive ESM support

\begin{tabular}{|c|c|c|c|c|c|c|}
\hline \multirow[b]{2}{*}{ support for EU transfers } & \multicolumn{2}{|c|}{ Model 1} & \multicolumn{2}{|c|}{ Model 2} & \multicolumn{2}{|c|}{ Model 3} \\
\hline & & & & & & \\
\hline social class & $0.050^{* * *}$ & $(0.013)$ & -0.004 & $(0.028)$ & -0.165 & $(0.887)$ \\
\hline support for domestic redistribution & 0.004 & $(0.003)$ & -0.006 & $(0.005)$ & $-0.391^{*}$ & $(0.176)$ \\
\hline GDP p.c. & $0.336^{*}$ & $(0.144)$ & $0.337^{*}$ & $(0.143)$ & 0.131 & $(0.183)$ \\
\hline exclusive national identity & $-0.387^{* * *}$ & $(0.019)$ & $-0.385^{* * *}$ & $(0.019)$ & $-0.383^{* * *}$ & $(0.019)$ \\
\hline cultural openness & $-0.118^{* * *}$ & $(0.008)$ & $-0.117^{* * *}$ & $(0.008)$ & $-0.116^{* * *}$ & $(0.008)$ \\
\hline education & $0.113^{* * *}$ & $(0.013)$ & $0.113^{* * *}$ & $(0.013)$ & $0.114^{* * *}$ & $(0.013)$ \\
\hline $\operatorname{sex}$ & $-0.081^{* * *}$ & $(0.016)$ & $-0.081^{* * *}$ & $(0.016)$ & $-0.082^{* * *}$ & $(0.016)$ \\
\hline age & $0.003^{* * *}$ & $(0.000)$ & $0.003^{* * *}$ & $(0.000)$ & $0.003^{* * *}$ & $(0.000)$ \\
\hline support for European integration & $0.074^{* * *}$ & $(0.003)$ & $0.074^{* * *}$ & $(0.003)$ & $0.074^{* * *}$ & $(0.003)$ \\
\hline deficit & 0.007 & $(0.011)$ & 0.007 & $(0.011)$ & 0.006 & $(0.011)$ \\
\hline debt & -0.001 & $(0.001)$ & -0.001 & $(0.001)$ & -0.001 & $(0.001)$ \\
\hline social expenditure as percent of GDP & 0.002 & $(0.013)$ & 0.002 & $(0.013)$ & 0.001 & $(0.013)$ \\
\hline social class $\times$ support for domestic redistrib. & & & $0.009^{*}$ & $(0.004)$ & 0.044 & $(0.134)$ \\
\hline social class $\times$ GDP p.c. & & & & & 0.017 & $(0.087)$ \\
\hline support for domestic redistrib. $\times$ GDP p.c. & & & & & $0.038^{*}$ & $(0.017)$ \\
\hline social class $\times$ support for domestic redistrib. $\times$ GDP p.c. & & & & & -0.004 & $(0.013)$ \\
\hline Constant & -1.458 & $(1.369)$ & -1.405 & $(1.368)$ & 0.683 & $(1.794)$ \\
\hline Observations level 1 & 10657 & & 10657 & & 10657 & \\
\hline Observations level 2 & 13 & & 13 & & 13 & \\
\hline
\end{tabular}

Standard errors in parentheses

${ }^{*} p<0.05,{ }^{* *} p<0.01,{ }^{* * *} p<0.001$ 
Table A8: Multilevel model, determinants of support for EU transfers; robustness check: economic left-right orientations operationalized with support for state interventions

\begin{tabular}{|c|c|c|c|c|c|c|}
\hline \multirow[b]{2}{*}{ social class (centered on middle class) } & \multicolumn{2}{|c|}{ Model 1} & \multicolumn{2}{|c|}{ Model 2} & \multicolumn{2}{|c|}{ Model 3} \\
\hline & $0.064^{* * *}$ & $(0.009)$ & $0.036^{*}$ & $(0.018)$ & -0.148 & $(0.581)$ \\
\hline support for state intervention & $0.011^{* * *}$ & $(0.002)$ & $0.011^{* * *}$ & $(0.002)$ & $-0.163^{*}$ & $(0.068)$ \\
\hline exclusive national identity & $-0.314^{* * *}$ & $(0.013)$ & $-0.314^{* * *}$ & $(0.013)$ & $-0.313^{* * *}$ & $(0.013)$ \\
\hline cultural openness & $-0.104^{* * *}$ & $(0.006)$ & $-0.104^{* * *}$ & $(0.006)$ & $-0.104^{* * *}$ & $(0.006)$ \\
\hline education & $0.102^{* * *}$ & $(0.009)$ & $0.102^{* * *}$ & $(0.009)$ & $0.102^{* * *}$ & $(0.009)$ \\
\hline $\operatorname{sex}$ & $-0.051^{* * *}$ & $(0.011)$ & $-0.051^{* * *}$ & $(0.011)$ & $-0.051^{* * *}$ & $(0.011)$ \\
\hline age & $0.003^{* * *}$ & $(0.000)$ & $0.003^{* * *}$ & $(0.000)$ & $0.003^{* * *}$ & $(0.000)$ \\
\hline support for European integration & $0.065^{* * *}$ & $(0.002)$ & $0.065^{* * *}$ & $(0.002)$ & $0.065^{* * *}$ & $(0.002)$ \\
\hline Eurozone member & $-0.225^{* *}$ & $(0.079)$ & $-0.225^{* *}$ & $(0.079)$ & $-0.225^{* *}$ & $(0.079)$ \\
\hline GDP per capita & $0.497^{* * *}$ & $(0.128)$ & $0.497^{* * *}$ & $(0.128)$ & $0.397^{* *}$ & $(0.134)$ \\
\hline deficit & -0.004 & $(0.012)$ & -0.004 & $(0.012)$ & -0.004 & $(0.012)$ \\
\hline debt & -0.000 & $(0.001)$ & -0.000 & $(0.001)$ & -0.000 & $(0.001)$ \\
\hline social expenditure as percent of GDP & -0.006 & $(0.010)$ & -0.006 & $(0.010)$ & -0.006 & $(0.010)$ \\
\hline social class $\times$ support for state intervention & & & $0.005^{+}$ & $(0.003)$ & 0.023 & $(0.094)$ \\
\hline support for state intervention $\times$ GDP per capita & & & & & $0.017^{*}$ & $(0.007)$ \\
\hline social class $\times$ GDP per capita & & & & & 0.019 & $(0.058)$ \\
\hline support for state intervention $\times$ soclass_cen $\times$ GDP per capita & & & & & -0.002 & $(0.009)$ \\
\hline Constant & $-2.825^{*}$ & $(1.198)$ & $-2.818^{*}$ & $(1.196)$ & -1.821 & $(1.259)$ \\
\hline Observations level 1 & 22346 & & 22346 & & 22346 & \\
\hline Observations level 2 & 28 & & 28 & & 28 & \\
\hline
\end{tabular}

standard errors in parentheses

$+p<0.10,{ }^{*} p<0.05,{ }^{* *} p<0.01,{ }^{* * *} p<0.001$ 
Table A9: Multilevel model, determinants of support for EU transfers; robustness check: controlling for ESM receiver countries

\begin{tabular}{|c|c|c|c|c|c|c|}
\hline \multirow[b]{2}{*}{ social class } & \multicolumn{2}{|c|}{ Model 1} & \multicolumn{2}{|c|}{ Model 2} & \multicolumn{2}{|c|}{ Model 3} \\
\hline & $0.060^{* * *}$ & $(0.009)$ & $-0.042^{*}$ & $(0.020)$ & 0.165 & $(0.611)$ \\
\hline support for domestic redistribution & -0.001 & $(0.002)$ & $-0.019^{* * *}$ & $(0.004)$ & $-0.291^{*}$ & $(0.113)$ \\
\hline exclusive national identity & $-0.310^{* * *}$ & $(0.013)$ & $-0.309^{* * *}$ & $(0.013)$ & $-0.307^{* * *}$ & $(0.013)$ \\
\hline cultural openness & $-0.108^{* * *}$ & $(0.006)$ & $-0.108^{* * *}$ & $(0.006)$ & $-0.106^{* * *}$ & $(0.006)$ \\
\hline education & $0.104^{* * *}$ & $(0.009)$ & $0.104^{* * *}$ & $(0.009)$ & $0.104^{* * *}$ & $(0.009)$ \\
\hline sex & $-0.053^{* * *}$ & $(0.011)$ & $-0.053^{* * *}$ & $(0.011)$ & $-0.054^{* * *}$ & $(0.011)$ \\
\hline age & $0.003^{* * *}$ & $(0.000)$ & $0.003^{* * *}$ & $(0.000)$ & $0.003^{* * *}$ & $(0.000)$ \\
\hline support for European integration & $0.064^{* * *}$ & $(0.002)$ & $0.064^{* * *}$ & $(0.002)$ & $0.064^{* * *}$ & $(0.002)$ \\
\hline Eurozone member & $-0.214^{* *}$ & $(0.080)$ & $-0.214^{* *}$ & $(0.079)$ & $-0.217^{* *}$ & $(0.080)$ \\
\hline GDP p.c. & $0.493^{* * *}$ & $(0.130)$ & $0.492^{* * *}$ & $(0.129)$ & 0.297 & $(0.151)$ \\
\hline deficit & -0.003 & $(0.012)$ & -0.003 & $(0.012)$ & -0.004 & $(0.012)$ \\
\hline debt & 0.000 & $(0.001)$ & 0.000 & $(0.001)$ & 0.001 & $(0.001)$ \\
\hline social expenditure as percent of GDP & -0.008 & $(0.011)$ & -0.008 & $(0.011)$ & -0.008 & $(0.011)$ \\
\hline receiver of ESM funds & -0.083 & $(0.119)$ & -0.082 & $(0.118)$ & -0.084 & $(0.119)$ \\
\hline social class $\times$ support for domestic redistrib. & & & $0.017^{* * *}$ & $(0.003)$ & -0.070 & $(0.089)$ \\
\hline support for domestic redistrib. $\times$ GDP p.c. & & & & & $0.027^{*}$ & $(0.011)$ \\
\hline social class $\times$ GDP p.c. & & & & & -0.019 & $(0.061)$ \\
\hline support for domestic redistrib. $\times$ social class $\times$ GDP p.c. & & & & & 0.008 & $(0.009)$ \\
\hline Constant & $-2.779^{*}$ & $(1.208)$ & $-2.655^{*}$ & $(1.202)$ & -0.707 & $(1.440)$ \\
\hline Observations level 1 & 22645 & & 22645 & & 22645 & \\
\hline Observations level 2 & 28 & & 28 & & 28 & \\
\hline
\end{tabular}

standard errors in parentheses
$+p<0.10,{ }^{*} p<0.05,{ }^{* *} p<0.01,{ }^{* * *} p<0.001$ 
Table A10: Multilevel model, determinants of support for EU transfers; robustness check: only including net contributors to EU budget

\begin{tabular}{|c|c|c|c|c|c|c|}
\hline \multirow[b]{2}{*}{ support for EU transfers } & \multicolumn{2}{|c|}{ Model 1} & \multicolumn{2}{|c|}{ Model 2} & \multicolumn{2}{|c|}{ Model 3} \\
\hline & & & & & & \\
\hline social class & $0.036^{* *}$ & $(0.013)$ & $-0.064^{*}$ & $(0.031)$ & -2.976 & $(3.751)$ \\
\hline support for domestic redistribution & $0.016^{* * *}$ & $(0.003)$ & -0.003 & $(0.006)$ & -0.764 & $(0.751)$ \\
\hline GDP p.c. & $0.920^{*}$ & $(0.428)$ & $0.924^{*}$ & $(0.425)$ & 0.219 & $(0.668)$ \\
\hline exclusive national identity & $-0.381^{* * *}$ & $(0.019)$ & $-0.379^{* * *}$ & $(0.019)$ & $-0.379^{* * *}$ & $(0.019)$ \\
\hline cultural openness & $-0.136^{* * *}$ & $(0.009)$ & $-0.135^{* * *}$ & $(0.009)$ & $-0.135^{* * *}$ & $(0.009)$ \\
\hline education & $0.101^{* * *}$ & $(0.013)$ & $0.102^{* * *}$ & $(0.013)$ & $0.102^{* * *}$ & $(0.013)$ \\
\hline $\operatorname{sex}$ & $-0.071^{* * *}$ & $(0.016)$ & $-0.071^{* * *}$ & $(0.016)$ & $-0.071^{* * *}$ & $(0.016)$ \\
\hline age & $0.002^{* * *}$ & $(0.000)$ & $0.002^{* * *}$ & $(0.000)$ & $0.002^{* * *}$ & $(0.000)$ \\
\hline support for European integration & $0.088^{* * *}$ & $(0.003)$ & $0.088^{* * *}$ & $(0.003)$ & $0.088^{* * *}$ & $(0.003)$ \\
\hline Eurozone member & $-0.174^{* *}$ & $(0.054)$ & $-0.171^{* *}$ & $(0.054)$ & $-0.172^{* *}$ & $(0.054)$ \\
\hline deficit & -0.020 & $(0.016)$ & -0.019 & $(0.016)$ & -0.018 & $(0.016)$ \\
\hline debt & -0.002 & $(0.002)$ & -0.002 & $(0.002)$ & -0.002 & $(0.002)$ \\
\hline social expenditure as percent of GDP & -0.010 & $(0.009)$ & -0.010 & $(0.009)$ & -0.010 & $(0.009)$ \\
\hline social class $\times$ support for domestic redistrib. & & & $0.016^{* * *}$ & $(0.004)$ & 0.154 & $(0.540)$ \\
\hline social class $\times$ GDP p.c. & & & & & 0.282 & $(0.362)$ \\
\hline support for domestic redistrib. $\times$ GDP p.c. & & & & & 0.074 & $(0.073)$ \\
\hline social class $\times$ support for domestic redistrib. $\times$ GDP p.c. & & & & & -0.013 & $(0.052)$ \\
\hline Constant & -7.134 & $(4.667)$ & -7.032 & $(4.630)$ & 0.252 & $(7.058)$ \\
\hline Observations level 1 & 9577 & & 9577 & & 9577 & \\
\hline Observations level 2 & 10 & & 10 & & 10 & \\
\hline
\end{tabular}

Standard errors in parentheses

${ }^{*} p<0.05,{ }^{* *} p<0.01,{ }^{* * *} p<0.001$ 
Table A11: Correlation between support for domestic redistribution (left-right ideology) and cultural orientations

\begin{tabular}{lc}
\hline country & correlation \\
\hline Austria & $-0.0757^{*}$ \\
Belgium & -0.0394 \\
Bulgaria & $0.0916^{*}$ \\
Croatia & 0.031 \\
Cyprus & 0.0717 \\
Czech Republic & 0.222 \\
Denmark & $-0.0947^{* *}$ \\
Estonia & 0.0318 \\
Finland & -0.0244 \\
France & $-0.1931^{* * *}$ \\
Germany & 0.0023 \\
Greece & 0.0111 \\
Hungary & $0.1115^{* * *}$ \\
Ireland & 0.0411 \\
Italy & -0.0314 \\
Latvia & $0.0909^{* *}$ \\
Lithuania & 0.0072 \\
Luxembourg & -0.0652 \\
Malta & 0.0609 \\
Netherlands & $-0.1596^{* * *}$ \\
Poland & $0.1139^{* *}$ \\
Portugal & 0.0305 \\
Romania & 0.0316 \\
Slovakia & $0.0746^{*}$ \\
Slovenia & $0.0641^{*}$ \\
Spain & $-0.0916^{* *}$ \\
Sweden & $-0.1237^{* * *}$ \\
United Kingdom & $-0.1248^{* * *}$ \\
\hline${ }^{*} p<0.05,{ }^{* *} p<0.01,{ }^{* * *} p<0.001$ \\
\end{tabular}


Table A12: Support for EU transfers by support for domestic redistribution (supplementary information for Figure 3)

\begin{tabular}{|c|c|c|c|c|c|}
\hline & \multicolumn{5}{|c|}{ support for EU transfers } \\
\hline & mean & $\mathrm{SD}$ & median & $\begin{array}{l}25 \text { th } \\
\text { per- } \\
\text { centile }\end{array}$ & $\begin{array}{l}75 \text { th } \\
\text { per- } \\
\text { centile }\end{array}$ \\
\hline $\begin{array}{l}\text { among respondents with limited } \\
\text { support for domestic redistribution }\end{array}$ & 2.48 & 0.95 & 3 & 2 & 3 \\
\hline $\begin{array}{l}\text { among respondents with moderate } \\
\text { support for domestic redistribution }\end{array}$ & 2.51 & 0.89 & 3 & 2 & 3 \\
\hline $\begin{array}{l}\text { among respondents with high sup- } \\
\text { port for domestic redistribution }\end{array}$ & 2.31 & 1.04 & 2 & 1 & 3 \\
\hline
\end{tabular}

Table A13: Support for EU transfers by support for domestic redistribution among individuals with high support for domestic redistribution (supplementary information for Figure 4)

\begin{tabular}{|c|c|c|c|c|c|}
\hline & \multicolumn{5}{|c|}{ support for EU transfers } \\
\hline & mean & $\mathrm{SD}$ & median & $\begin{array}{l}25 \text { th } \\
\text { per- } \\
\text { centile }\end{array}$ & $\begin{array}{l}75 \text { th } \\
\text { per- } \\
\text { centile }\end{array}$ \\
\hline \multicolumn{6}{|l|}{ social classes: } \\
\hline low social class & 2.03 & 1.02 & 2 & 1 & 3 \\
\hline middle class & 2.39 & 1.02 & 3 & 1 & 3 \\
\hline high social class & 2.59 & 1.04 & 3 & 2 & 3 \\
\hline \multicolumn{6}{|l|}{ occupational groups: } \\
\hline unemployed & 2.16 & 1.06 & 2 & 1 & 3 \\
\hline unskilled labor & 2.08 & 1.13 & 2 & 1 & 3 \\
\hline skilled labor & 2.31 & 1.04 & 2 & 1 & 3 \\
\hline small business owners & 2.18 & 1.02 & 2 & 1 & 3 \\
\hline employed professionals & 2.60 & 0.98 & 3 & 2 & 3 \\
\hline middle management & 2.67 & 1.01 & 3 & 2 & 3 \\
\hline $\begin{array}{l}\text { self-employed professionals and } \\
\text { managers }\end{array}$ & 2.65 & 1.05 & 3 & 2 & 3 \\
\hline
\end{tabular}


Table A14: Multilevel model, determinants of support for EU transfers, aggregate economic evaluations instead of GNI per capita

\begin{tabular}{|c|c|c|c|c|c|c|}
\hline \multirow[b]{2}{*}{ social class } & \multicolumn{2}{|c|}{$\begin{array}{c}(1) \\
\text { support for EU transfers }\end{array}$} & \multicolumn{2}{|c|}{$\begin{array}{c}(2) \\
\text { support for EU transfers }\end{array}$} & \multicolumn{2}{|c|}{$\begin{array}{c}(3) \\
\text { support for EU transfers }\end{array}$} \\
\hline & $-0.043^{*}$ & $(0.020)$ & $-0.042^{*}$ & $(0.020)$ & $-0.042^{*}$ & $(0.020)$ \\
\hline support for domestic redistribution & $-0.019^{* * *}$ & $(0.004)$ & $-0.019^{* * *}$ & $(0.004)$ & $-0.019^{* * *}$ & $(0.004)$ \\
\hline social class $\times$ support for domestic redistrib. & $0.017^{* * *}$ & $(0.003)$ & $0.017^{* * *}$ & $(0.003)$ & $0.017^{* * *}$ & $(0.003)$ \\
\hline exclusive national identity & $-0.309^{* * *}$ & $(0.013)$ & $-0.309^{* * *}$ & $(0.013)$ & $-0.309^{* * *}$ & $(0.013)$ \\
\hline cultural openness & $-0.108^{* * *}$ & $(0.006)$ & $-0.108^{* * *}$ & $(0.006)$ & $-0.108^{* * *}$ & $(0.006)$ \\
\hline education & $0.104^{* * *}$ & $(0.009)$ & $0.104^{* * *}$ & $(0.009)$ & $0.104^{* * *}$ & $(0.009)$ \\
\hline $\operatorname{sex}$ & $-0.053^{* * *}$ & $(0.011)$ & $-0.053^{* * *}$ & $(0.011)$ & $-0.053^{* * *}$ & $(0.011)$ \\
\hline age & $0.003^{* * *}$ & $(0.000)$ & $0.003^{* * *}$ & $(0.000)$ & $0.003^{* * *}$ & $(0.000)$ \\
\hline support for European integration & $0.064^{* * *}$ & $(0.002)$ & $0.064^{* * *}$ & $(0.002)$ & $0.064^{* * *}$ & $(0.002)$ \\
\hline Eurozone member & $-0.217^{* *}$ & $(0.080)$ & -0.087 & $(0.082)$ & -0.106 & $(0.082)$ \\
\hline deficit & -0.004 & $(0.013)$ & 0.004 & $(0.014)$ & 0.007 & $(0.013)$ \\
\hline debt & -0.000 & $(0.001)$ & 0.000 & $(0.001)$ & 0.000 & $(0.001)$ \\
\hline social expenditure as percent of GDP & -0.012 & $(0.011)$ & 0.017 & $(0.009)$ & 0.016 & $(0.009)$ \\
\hline GNI per capita & $0.573^{* * *}$ & $(0.158)$ & & & & \\
\hline $\begin{array}{l}\text { aggregate retrospect. sociotropic econ. eval. } \\
\text { aggregate prospect. sociotropic econ. eval. }\end{array}$ & & & $0.193^{*}$ & $(0.088)$ & $0.256^{*}$ & $(0.119)$ \\
\hline Constant & $-3.536^{*}$ & $(1.506)$ & $1.314^{* * *}$ & $(0.313)$ & $1.105^{* *}$ & $(0.402)$ \\
\hline Observations & 22645 & & 22645 & & 22645 & \\
\hline
\end{tabular}

\begin{tabular}{l}
\hline \hline Standard errors in parentheses \\
${ }^{*} p<0.05,{ }^{* *} p<0.01,{ }^{* * *} p<0.001$
\end{tabular}




\section{Causal Mediation Analysis}

(see Appendix Table A15 and A16)
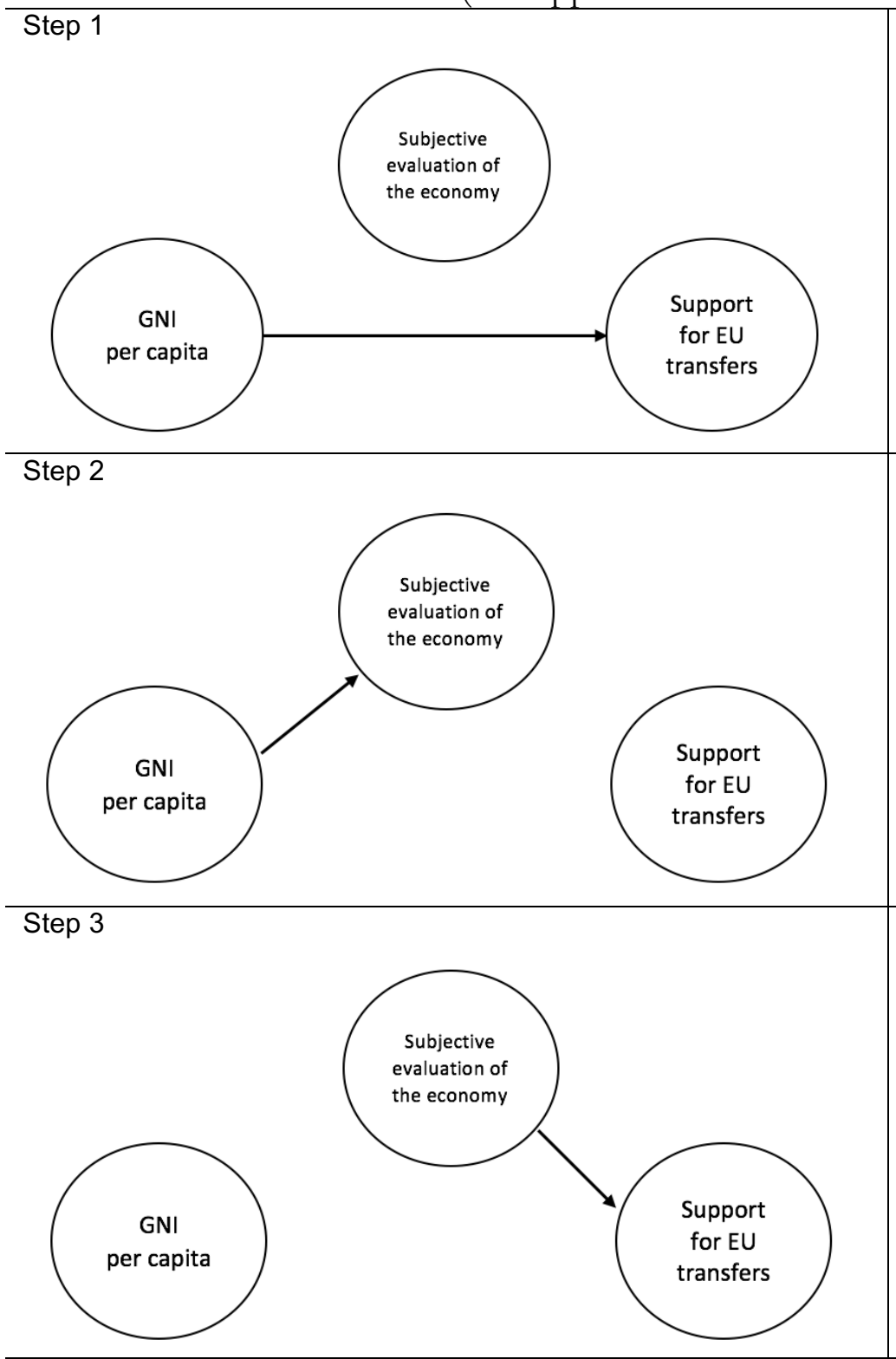

Step 4

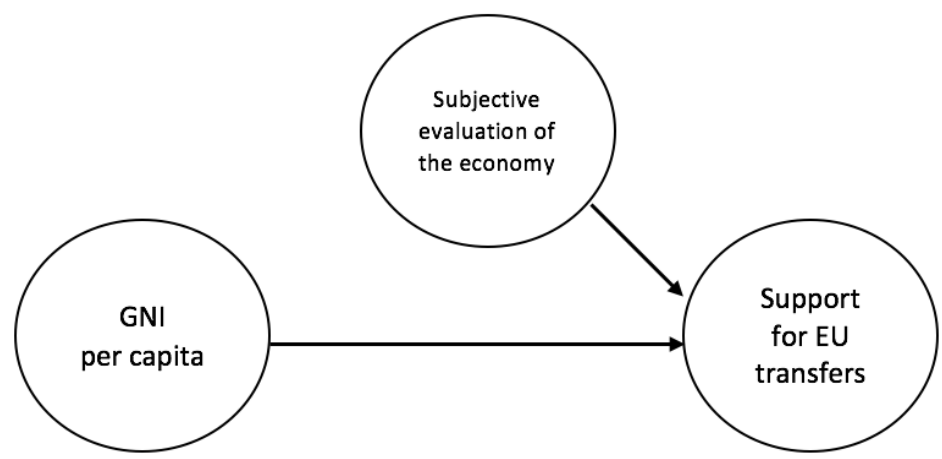

Model 1 shows a positive and significant regression coefficient when regressing support for EU transfers on GNI per capita. That is, support for EU transfers is higher in richer countries.

In model 2, we regress retrospective sociotropic economic evaluations on GNI per capita. We find that citizens in richer countries believe that the state of the economy is doing better.
In model 3, we regress support for EU transfers on perceptions of the economy but we exclude GNI per capita. We find that citizens who believe the country is doing well economically exhibit more support for EU transfers.
In model 4, we regress support for EU transfers on GNI per capita and on perceptions of the economy simultaneously. We find that the effect of GNI per capita is smaller when perceptions of the economy are inserted simultaneously. This pattern of results is consistent with partial mediation (Baron and Kenney 1986: 1176), that is, a share of the relationship between GNI per capita and support for EU transfers is explained by retrospective evaluations of the economy. We believe that evaluations of the economy are an imprecise measure for what a country can afford, which needs to be taken into account when evaluating the mediation. Yet, the results are consistent with the notion that citizens are more likely to support EU transfer when they think their country can afford it and less likely when they believe their country cannot afford it. 
Table A15: Causal Mediation Analysis, using retrospective sociotropic economic evaluations

\begin{tabular}{|c|c|c|c|c|c|c|c|c|}
\hline \multirow[b]{2}{*}{ social class } & \multicolumn{2}{|c|}{$\begin{array}{c}\text { Model } 1 \\
\text { support for EU transfers }\end{array}$} & \multicolumn{2}{|c|}{$\begin{array}{c}\text { Model } 2 \\
\text { retrosp. sociotr. econ. eval. }\end{array}$} & \multicolumn{2}{|c|}{$\begin{array}{c}\text { Model } 3 \\
\text { support for EU transfers }\end{array}$} & \multicolumn{2}{|c|}{$\begin{array}{c}\text { Model } 4 \\
\text { support for EU transfers }\end{array}$} \\
\hline & $-0.043^{*}$ & $(0.020)$ & $0.069^{* * *}$ & $(0.020)$ & $-0.053^{* *}$ & $(0.020)$ & $-0.053^{* *}$ & $(0.020)$ \\
\hline support for domestic redistribution & $-0.019^{* * *}$ & $(0.004)$ & $-0.027^{* * *}$ & $(0.004)$ & $-0.016^{* * *}$ & $(0.004)$ & $-0.016^{* * *}$ & $(0.004)$ \\
\hline social class $\times$ support for domestic redistrib. & $0.017^{* * *}$ & $(0.003)$ & $0.010^{* * *}$ & $(0.003)$ & $0.016^{* * *}$ & $(0.003)$ & $0.016^{* * *}$ & $(0.003)$ \\
\hline exclusive national identity & $-0.309^{* * *}$ & $(0.013)$ & $-0.224^{* * *}$ & $(0.013)$ & $-0.285^{* * *}$ & $(0.013)$ & $-0.285^{* * *}$ & $(0.013)$ \\
\hline cultural openness & $-0.108^{* * *}$ & $(0.006)$ & $-0.035^{* * *}$ & $(0.006)$ & $-0.102^{* * *}$ & $(0.006)$ & $-0.102^{* * *}$ & $(0.006)$ \\
\hline education & $0.104^{* * *}$ & $(0.009)$ & $0.064^{* * *}$ & $(0.009)$ & $0.096^{* * *}$ & $(0.009)$ & $0.096^{* * *}$ & $(0.009)$ \\
\hline $\operatorname{sex}$ & $-0.053^{* * *}$ & $(0.011)$ & $-0.095^{* * *}$ & $(0.012)$ & $-0.047^{* * *}$ & $(0.011)$ & $-0.047^{* * *}$ & $(0.011)$ \\
\hline age & $0.003^{* * *}$ & $(0.000)$ & 0.001 & $(0.000)$ & $0.003^{* * *}$ & $(0.000)$ & $0.003^{* * *}$ & $(0.000)$ \\
\hline support for European integration & $0.064^{* * *}$ & $(0.002)$ & $0.027^{* * *}$ & $(0.002)$ & $0.061^{* * *}$ & $(0.002)$ & $0.061^{* * *}$ & $(0.002)$ \\
\hline Eurozone member & $-0.217^{* *}$ & $(0.080)$ & $-0.345^{*}$ & $(0.139)$ & -0.086 & $(0.084)$ & $-0.179^{*}$ & $(0.082)$ \\
\hline deficit & -0.004 & $(0.013)$ & 0.005 & $(0.022)$ & 0.007 & $(0.014)$ & -0.004 & $(0.013)$ \\
\hline debt & -0.000 & $(0.001)$ & 0.000 & $(0.002)$ & -0.000 & $(0.001)$ & -0.000 & $(0.001)$ \\
\hline social expenditure as percent of GDP & -0.012 & $(0.011)$ & $-0.069^{* * *}$ & $(0.020)$ & $0.018^{*}$ & $(0.009)$ & -0.004 & $(0.012)$ \\
\hline GNI per capita & $0.573^{* * *}$ & $(0.158)$ & $1.176^{* * *}$ & $(0.274)$ & & & $0.440^{* *}$ & $(0.161)$ \\
\hline retrospective sociotropic econ. eval. & & & & & $0.113^{* * *}$ & $(0.006)$ & $0.112^{* * *}$ & $(0.006)$ \\
\hline Constant & $-3.536^{*}$ & $(1.506)$ & $-8.081^{* *}$ & $(2.609)$ & $1.560^{* * *}$ & $(0.164)$ & -2.611 & $(1.534)$ \\
\hline Observations level 1 & 22645 & & 22874 & & 22424 & & 22424 & \\
\hline Observations level 2 & 28 & & 28 & & 28 & & 28 & \\
\hline
\end{tabular}

\footnotetext{
Standard errors in parentheses

${ }^{*} p<0.05,{ }^{* *} p<0.01,{ }^{* * *} p<0.001$
} 
Table A16: Causal Mediation Analysis, using prospective sociotropic economic evaluations

\begin{tabular}{|c|c|c|c|c|c|c|c|c|}
\hline \multirow[b]{2}{*}{ social class } & \multicolumn{2}{|c|}{$\begin{array}{c}\text { Model } 1 \\
\text { support for EU transfers }\end{array}$} & \multicolumn{2}{|c|}{$\begin{array}{c}\text { Model } 2 \\
\text { prosp. sociotr. econ. eval. }\end{array}$} & \multicolumn{2}{|c|}{$\begin{array}{c}\text { Model } 3 \\
\text { support for EU transfers }\end{array}$} & \multicolumn{2}{|c|}{$\begin{array}{c}\text { Model } 4 \\
\text { support for EU transfers }\end{array}$} \\
\hline & $-0.043^{*}$ & $(0.020)$ & 0.024 & $(0.020)$ & $-0.044^{*}$ & $(0.020)$ & $-0.045^{*}$ & $(0.020)$ \\
\hline support for domestic redistribution & $-0.019^{* * *}$ & $(0.004)$ & $-0.033^{* * *}$ & $(0.004)$ & $-0.015^{* * *}$ & $(0.004)$ & $-0.015^{* * *}$ & $(0.004)$ \\
\hline social class $\times$ support for domestic redistrib. & $0.017^{* * *}$ & $(0.003)$ & $0.015^{* * *}$ & $(0.003)$ & $0.015^{* * *}$ & $(0.003)$ & $0.015^{* * *}$ & $(0.003)$ \\
\hline exclusive national identity & $-0.309^{* * *}$ & $(0.013)$ & $-0.282^{* * *}$ & $(0.013)$ & $-0.274^{* * *}$ & $(0.013)$ & $-0.274^{* * *}$ & $(0.013)$ \\
\hline cultural openness & $-0.108^{* * *}$ & $(0.006)$ & $-0.035^{* * *}$ & $(0.006)$ & $-0.103^{* * *}$ & $(0.006)$ & $-0.103^{* * *}$ & $(0.006)$ \\
\hline education & $0.104^{* * *}$ & $(0.009)$ & $0.029^{* *}$ & $(0.009)$ & $0.101^{* * *}$ & $(0.009)$ & $0.101^{* * *}$ & $(0.009)$ \\
\hline $\operatorname{sex}$ & $-0.053^{* * *}$ & $(0.011)$ & $-0.045^{* * *}$ & $(0.011)$ & $-0.050^{* * *}$ & $(0.011)$ & $-0.050^{* * *}$ & $(0.011)$ \\
\hline age & $0.003^{* * *}$ & $(0.000)$ & $0.002^{* * *}$ & $(0.000)$ & $0.003^{* * *}$ & $(0.000)$ & $0.003^{* * *}$ & $(0.000)$ \\
\hline support for European integration & $0.064^{* * *}$ & $(0.002)$ & $0.029^{* * *}$ & $(0.002)$ & $0.061^{* * *}$ & $(0.002)$ & $0.062^{* * *}$ & $(0.002)$ \\
\hline Eurozone member & $-0.217^{* *}$ & $(0.080)$ & -0.164 & $(0.111)$ & -0.091 & $(0.085)$ & $-0.193^{*}$ & $(0.081)$ \\
\hline deficit & -0.004 & $(0.013)$ & -0.003 & $(0.017)$ & 0.009 & $(0.014)$ & -0.004 & $(0.013)$ \\
\hline debt & -0.000 & $(0.001)$ & -0.001 & $(0.002)$ & -0.000 & $(0.001)$ & -0.000 & $(0.001)$ \\
\hline social expenditure as percent of GDP & -0.012 & $(0.011)$ & $-0.040^{*}$ & $(0.016)$ & 0.017 & $(0.009)$ & -0.007 & $(0.011)$ \\
\hline GNI per capita & $0.573^{* * *}$ & $(0.158)$ & $0.761^{* * *}$ & $(0.218)$ & & & $0.485^{* *}$ & $(0.160)$ \\
\hline prospective sociotropic econ. eval. & & & & & $0.120^{* * *}$ & $(0.007)$ & $0.120^{* * *}$ & $(0.007)$ \\
\hline Constant & $-3.536^{*}$ & $(1.506)$ & $-4.098^{*}$ & $(2.082)$ & $1.509^{* * *}$ & $(0.167)$ & $-3.095^{*}$ & $(1.524)$ \\
\hline Observations level 1 & 22645 & & 22317 & & 21899 & & 21899 & \\
\hline Observations level 2 & 28 & & 28 & & 28 & & 28 & \\
\hline
\end{tabular}

\footnotetext{
Standard errors in parentheses

${ }^{*} p<0.05,{ }^{* *} p<0.01,{ }^{* * *} p<0.001$
} 


\section{Online Appendix B: Variable Coding}

\section{Dependent variable (from EES 2014):}

Support for EU transfers: To what extent do you agree or disagree with the following statement? In times of crisis, it is desirable for Germany to give financial help to another EU Member State facing severe economic and financial difficulties. Four response categories, coded in the following way: $1=$ totally disagree, $2=$ tend to disagree, $3=$ tend to agree, $4=$ totally agree

\section{Independent variables (from EES 2014):}

Social class: Could you please tell me where you would place yourself on the following scale? Where ' 1 ' corresponds to "the lowest level in society" and '10' corresponds to "the highest level in society. Responses are coded in the following way, as offered by D61r of the dataset: $1-4=$ low social class, $5-6=$ middle class, $7-10$ upper social class.

Support for domestic redistribution: We would like to ask you to position yourself on a scale from 0 to 10 , where ' 0 ' means that you "fully agree with the statement at the top" and '10' means that you "fully agree with the statement at the bottom". Then if your views are somewhere in between, you can choose any number that describes your position best: [0] You are fully in favour of the redistribution of wealth from the rich to the poor in (OUR COUNTRY), [10] You are fully opposed to the redistribution of wealth from the rich to the poor in (OUR COUNTRY). Recoded: $0=$ low support for domestic redistribution; $10=$ high support for domestic redistribution

Exclusive national identity: For each of the following statements, please tell me to what extent it corresponds or not to your attitude or opinion: You feel you are a citizen of the EU. Yes, definitely $=1$, Yes, to some extent $=2$, No, not really $=3$, No, not at all $=4$. Recoded: exclusive national identity $=1$ (no European identity present: No, not really $=$ $3 \&$ No, not at all $=4$ ), exclusive national identity $=0$ (European identity present: Yes, definitely $=1$, Yes, to some extent $=2$ )

Cultural orientations: We combine three variables using their common factor: a question on same-sex marriages, a question on civil liberties, and a question on attitudes towards immigrants. The range of the common factor is -2.8 (culturally closed position) to 2.5 (culturally open position). Question wording: We would like to ask you to position yourself on a scale from 0 to 10 , where ' 0 ' means that you "fully agree with the statement at the top" and '10' means that you "fully agree with the statement at the bottom". Then if your views are somewhere in between, you can choose any number that describes your position best. 1) same-sex marriage: [0] You are fully in favour of same-sex marriage, [10] You are fully opposed to same-sex marriage; 2) civil liberties: [0] You fully support privacy rights even if they hinder efforts to combat crime, [10] You are fully in favour of restricting privacy rights in order to combat crime; 3) immigration: [0] You are fully in favour of a restrictive policy on immigration, [10] You are fully opposed to a restrictive policy on immigration.

Education: How old were you when you stopped full-time education? Replies coded in the following way: education low $(0)=$ education until the age of 15 or less; education medium (1) = education until the ages 16-19; education high = education until the age of 20 or more \& still studying 
EU support: Some say European unification should be pushed further. Others say it already has gone too far. What is your opinion? Please indicate your views using a scale from 0 to 10 , where ' 0 ' means unification "has already gone too far" and ' 10 ' means it "should be pushed further". What number on this scale best describes your position? [0] European unification has already gone too far, [10] European unification should be pushed further

Financial standing: During the last 12 months, would you say you had difficulties to pay your bills? Replies recoded: $0=$ most of the time, $1=$ from time to time, $2=$ almost never/never

Occupation: What is your current occupation? Replies recoded according to Oesch (2016) scheme displayed in Table A5.

Retrospective sociotropic evaluation: "And over the next 12 months, how do you think the general economic situation in [country] will be? Will it...?” $0=$ get a lot worse, $1=$ get a little worse, $2=$ stay the same, $3=$ get a little better, $4=$ get a lot better. $\mathrm{DK}=$ excluded.

Prospective sociotropic evaluations: "What do you think about the economy? compared to 12 months ago, do you think that the general economic situation in [country] ?" $0=$ is a lot worse, $1=$ is a little worse, $2=$ stayed the same, $3=$ is a little better, $4=$ is a lot better, $\mathrm{DK}=$ excluded

Age: in years; Sex: $0=$ male, $1=$ female

\section{Independent variables from other sources:}

Eurozone dummy: 0 for all EU member states that are not part of the Eurozone and 1 for all EU member states that are part of the Eurozone

Debt: General government consolidated gross debt as a percentage of GDP (Eurostat 2013), http://ec.europa.eu/eurostat/data/database

Deficit: Net lending $(+)$ / net borrowing $(-)$ of the general government as a percentage of GDP (Eurostat 2013), http:/ / ec.europa.eu/eurostat/data/database

Social GDP: General government expenditure on social protection as a percentage of GDP (Eurostat 2013), http:/ / ec.europa.eu/eurostat/data/database

GNI p.c.: Gross National Income per inhabitant in Purchasing Power Parity 2013, The World Bank: http://databank.worldbank.org/data

GDP p.c.: Gross Domestic Product per inhabitant in Purchasing Power Parity, (Eurostat 2013), http://ec.europa.eu/eurostat/data/database

EU net budget contributions: net contributions to the EU budget of each EU member state as a percentage of this country's Gross National Income (Source: EU Budget 2014 Financial Report, Publications Office of the European Union, Luxembourg 2015, p.145. 